$10-2009$

\title{
Improving the Quality of Spiritual Care as a Dimension of Palliative Care: The Report of the Consensus Conference
}

\author{
Christina Puchalski \\ George Washington University \\ Betty Ferrell \\ City of Hope National Medical Center \\ Rose Virani \\ City of Hope National Medical Center \\ Shirley Otis-Green \\ City of Hope National Medical Center \\ Pamela Baird \\ City of Hope National Medical Center \\ Follow this and additional works at: https://ecommons.luc.edu/socialwork_facpubs \\ fia next page for additional authors \\ Part of the Social Work Commons
}

\section{Recommended Citation}

Christina Puchalski, Betty Ferrell, Rose Virani, Shirley Otis-Green, Pamela Baird, Janet Bull, Harvey Chochinov, George Handzo, Holly Nelson-Becker, Maryjo Prince-Paul, Karen Pugliese, and Daniel Sulmasy. "Improving the Quality of Spiritual Care as a Dimension of Palliative Care: The Report of the Consensus Conference." Journal of Palliative Medicine. October 2009, 12(10): 885-904. doi:10.1089/jpm.2009.0142.

This Article is brought to you for free and open access by the Faculty Publications and Other Works by Department at Loyola eCommons. It has been accepted for inclusion in Social Work: School of Social Work Faculty Publications and Other Works by an authorized administrator of Loyola eCommons. For more information, please contact ecommons@luc.edu.

\section{c) (i) $\odot$}

This work is licensed under a Creative Commons Attribution-Noncommercial-No Derivative Works 3.0 License. (c) 2009, Mary Ann Liebert, Inc. 


\section{Authors}

Christina Puchalski, Betty Ferrell, Rose Virani, Shirley Otis-Green, Pamela Baird, Janet Bull, Harvey Chochinov, George Handzo, Holly Nelson-Becker, Maryjo Prince-Paul, Karen Pugliese, and Daniel Sulmasy 


\title{
Improving the Quality of Spiritual Care as a Dimension of Palliative Care: The Report of the Consensus Conference
}

\author{
Christina Puchalski, M.D., M.S., F.A.P.C., Betty Ferrell, Ph.D., M.A., F.A.A.N., F.P.C.N., ${ }^{2}$ \\ Rose Virani, R.N.C., M.H.A., O.C.N., ${ }^{\circledR}$ F.P.C.N., ${ }^{2}$ Shirley Otis-Green, M.S.W., L.C.S.W., A.C.S.W., O.S.W.-C., ${ }^{2}$ \\ Pamela Baird, A.A., ${ }^{2}$ Janet Bull, M.A., Harvey Chochinov, M.D., Ph.D., F.R.C.P.C., ${ }^{3}$ \\ George Handzo, M.Div., B.C.C., M.A., Holly Nelson-Becker, M.S.W., Ph.D., \\ Maryjo Prince-Paul, Ph.D., A.P.R.N., A.C.H.P.N., ${ }^{6}$ \\ Karen Pugliese, M.A., B.C.C., ${ }^{7}$ and Daniel Sulmasy, O.F.M., M.D., Ph.D. ${ }^{8}$
}

\begin{abstract}
A Consensus Conference sponsored by the Archstone Foundation of Long Beach, California, was held February 17-18, 2009, in Pasadena, California. The Conference was based on the belief that spiritual care is a fundamental component of quality palliative care. This document and the conference recommendations it includes builds upon prior literature, the National Consensus Project Guidelines, and the National Quality Forum Preferred Practices and Conference proceedings.
\end{abstract}

\section{Introduction}

I N THE EARLY 1990s, academic medical centers, medical and nursing schools, residency programs, and hospitals began to recognize the role of spiritual care as a dimension of palliative care. A growing body of literature $\mathrm{e}^{1-5}$ as well as attention from the lay press $^{6-8}$ raised awareness of and questions about the role of spirituality in health care. Surveys have demonstrated that spirituality is a patient need, ${ }^{9,10}$ that it affects health care decision-making, ${ }^{11,12}$ and that spirituality affects health care outcomes including quality of life. ${ }^{13-18}$ Spiritual and religious beliefs can also create distress and increase the burdens of illness. ${ }^{19,20}$

Studies have raised critical issues including the need for a commonly accepted definition of spirituality, the appropriate application of spiritual care in palliative care settings, clarification about who should deliver spiritual care, the role of health care providers in spiritual care, and ways to increase scientific rigor surrounding spirituality and spiritual care research and practice. These issues and the current variability in delivering spiritual care as a component of palliative care raised awareness of the need for guidelines for ensuring quality care. To this end, a Consensus Conference sponsored by the Archstone Foundation of Long Beach, California, was held February 17-18, 2009, in Pasadena, California. The Conference was based on the belief that spiritual care is a fundamental component of quality palliative care. According to the National Consensus Project (NCP) for Quality Palliative Care, ${ }^{21}$ "The goal of palliative care is to prevent and relieve suffering and to support the best possible quality of life for patients and their families, regardless of the stage of the disease or the need for other therapies." Palliative care is viewed as applying to patients from the time of diagnosis of serious illness to death. In this way, the principles of spiritual care can be applicable across all phases and settings for the seriously ill, without regard to culture, religious tradition, or spiritual frames of reference.

The goal of the Consensus Conference was to identify points of agreement about spirituality as it applies to health care and to make recommendations to advance the delivery of quality spiritual care in palliative care. Five literature-based categories of spiritual care (spiritual assessment, models of care and care plans, interprofessional team training, quality improvement, and personal and professional development)

\footnotetext{
${ }^{1}$ George Washington Institute for Spirituality and Health, The George Washington University, Washington, D.C.

${ }^{2}$ City of Hope National Medical Center, Duarte, California.

${ }^{3}$ CancerCare MB, McDermot, Winnipeg, Manitoba, Canada.

${ }^{4}$ HealthCare Chaplaincy, New York, New York.

${ }^{5}$ University of Kansas, Lawrence, Kansas.

${ }^{6}$ Frances Payne Bolton School of Nursing, Cleveland, Ohio.

${ }^{7}$ Central Dupage Hospital, Winfield, Illinois.

${ }^{8}$ The University of Chicago, Chicago, Illinois.
} 
were identified and provided the framework for the Consensus Conference. The resulting document and conference recommendations builds upon prior literature, the NCP Guidelines $^{21}$ and National Quality Forum (NQF) Preferred Practices $^{22}$ and Conference proceedings. This article represents the final Consensus Report. An expanded description of the Conference content and each section of this article is currently in preparation and will be published as a book.

\section{Palliative Care Guidelines and Preferred Practices}

The first clinical practice guidelines for palliative care were released in 2004 by the $\mathrm{NCP}^{23}$; the guidelines were revised and a second edition was published in $2009 .^{21}$ These guidelines are applicable to specialist-level palliative care (e.g., palliative care teams) delivered in a wide range of treatment settings and to the work of providers in primary treatment settings where palliative approaches to care are integrated into daily clinical practice (e.g., oncology, critical care, long-term care). Specifically these Clinical Practice Guidelines are intended to

1. Facilitate the development and improvement of clinical palliative care programs providing care to diverse patients and families with life-limiting or debilitating illness.

2. Establish uniformly accepted definitions of the essential elements in palliative care that promote quality, consistency, and reliability of these services.

3. Establish national goals for access to quality palliative care.

4. Foster performance measurement and quality improvement initiatives in palliative care services.

The guidelines address eight domains of care: structure and processes; physical aspects; psychological and psychiatric aspects; social aspects; spiritual, religious, and existential aspects; cultural aspects; imminent death; and ethical and legal aspects.

The successful dissemination of the NCP guidelines led next to collaboration with the NQF. Building on the NCP Guidelines, the NQF released a set of preferred practices for palliative care in $2006 .^{22}$ This was a major advancement in the field of palliative care given the status of NQF as the nation's major private-public partnership responsible for identifying and approving evidence-based quality measures linked to reimbursement in all parts of the health care system. NQF involvement also was crucial in attracting the interest of policymakers in this field. Using the $8 \mathrm{NCP}$ domains for its framework structure, the NQF identified 38 preferred practices to operationalize the NCP Guidelines and to set the foundation for future measurement of the outcomes of care. These practices are evidence-based or have been endorsed through expert opinion and apply to both hospice and palliative care. The 2009 NCP Guidelines ${ }^{21}$ and the NQF Preferred Practices $^{22}$ (Table 1) served as the foundation for the recommendations for the Consensus Conference.

\section{Consensus Conference Design and Organization}

Achieving a consensus on spiritual care, both conceptually and pragmatically, requires engagement, deliberation, and dialogue among key stakeholders. Conference participation was by invitation. Invitees included a representative sample of 40 national leaders, including physicians, nurses, psychologists, social workers, chaplains and clergy, other spiritual care providers, and health care administrators (Table 2). Participants agreed to develop a consensus-driven definition of spirituality, make recommendations to improve spiritual care in palliative care settings, identify resources to advance the quality of spiritual care to be made available through the George Washington Institute for Spirituality and Health SOERCE website, ${ }^{24}$ and help with dissemination of the final documents. Prior to the conference, participants received a written overview of spiritual care as a dimension of palliative care drafted by Christina Puchalski, M.D. and Betty Ferrell, Ph.D., R.N., Principal Investigators. This document was, in effect, the first draft of this Consensus Report and incorporated feedback from an advisory committee and conference participants. It provided a common base from which the group could identify recommendations to improve spiritual care.

The conference began with an overview of the purpose of the conference, its structure, and its relation to the existing NCP guidelines and NQF preferred practices. This was followed by an overview of the developing Consensus Report, its structure, and areas of agreement and disagreement based the participants' reviews. The conference was facilitated by a consultant who established "ground rules" to create a safe environment for discussion and disagreement, for sharing all ideas, and for respect and the opportunity to speak without fear of judgment about diverse views.

At the conclusion of the first plenary session, participants attended one of five preassigned working groups each with an assigned facilitator. Each working group developed a proposed definition of spirituality and identified the key components of spirituality. After the first working group session, participants reviewed all the definitions and components and, using a consensus process, reached initial agreement on a definition and its important components.

The second plenary session began with a brief overview of the literature in spirituality and spiritual care. This was followed by a second working group session in which participants (in their same preassigned groups) were asked to focus on one of five key areas of spiritual care: Models and Treatment Plans, Assessment, Interprofessional Team/Training, Quality Improvement, and Personal and Professional Development. Facilitators asked each group to consider the following questions according to their specific group topic:

1. What are the issues identified in addressing the topic in spiritual care?

2. What are the barriers in implementing the topic?

3. What are the recommendations for the topic in applying spiritual care as a dimension of palliative care?

4. What resources or implementation strategies are available for the topic?

5. The conference facilitator received all of the written notes from the working groups, synthesized all the comments, and prepared a compilation for all participants to discuss on Day 2.

On Day 2, using a consensus process, conference participants finalized the definition of spirituality within the context of a health care environment. Critical elements of the definition included meaning, connectedness to spirituality as an aspect of humanity, and the search for the significant or sacred. In addition, spirituality was defined as being inclusive 
Table 1. National Consensus Project Guidelines ${ }^{21}$ and National Quality Preferred Practices for SPIRITUAL DOMAIN ${ }^{22}$

National Consensus Project Guidelines spiritual domain

Guideline 5.1 Spiritual and existential dimensions are assessed and responded to based upon the best available evidence, which is skillfully and systematically applied. Criteria:

- The interdisciplinary team includes professionals with skill in assessment of and response to the spiritual and existential issues common to both pediatric and adult patients with life-threatening illnesses and conditions, and their families. These professionals should have education and appropriate training in pastoral care and the spiritual issues evoked by patients and families faced with life-threatening illness.

- The regular assessment of spiritual and existential concerns is documented. This includes, but is not limited to, life review, assessment of hopes and fears, meaning, purpose, beliefs about afterlife, guilt, forgiveness, and life completion tasks.

- Whenever possible a standardized instrument should be used to assess and identify religious or spiritual/ existential background, preferences, and related beliefs, rituals, and practices of the patient and family.

- Periodic reevaluation of the impact of spiritual/ existential interventions and patient-family preferences should occur with regularity and be documented. Spiritual/existential care needs, goals, and concerns are addressed and documented, and support is offered for issues of life completion in a manner consistent with the individual's and family's cultural and religious values.

- Pastoral care and other palliative care professionals facilitate contacts with spiritual/religious communities, groups or individuals, as desired by the patient and/or family. Of primary importance is that patients have access to clergy in their own religious traditions.

- Professional and institutional use of religious/spiritual symbols is sensitive to cultural and religious diversity.

- The patient and family are encouraged to display their own religious/spiritual or cultural symbols.

- The palliative care service facilitates religious or spiritual rituals or practices as desired by patient and family, especially at the time of death.

- Referrals to professionals with specialized knowledge or skills in spiritual and existential issues are made when appropriate.
National Quality Forum preferred practices

DOMAIN 5.

SPIRITUAL, RELIGIOUS, AND EXISTENTIAL ASPECTS OF CARE

PREFERRED PRACTICE 20

Develop and document a plan based on assessment of religious, spiritual, and existential concerns using a structured instrument and integrate the information obtained from the assessment into the palliative care plan.

\section{PREFERRED PRACTICE 21}

Provide information about the availability of spiritual care services and make spiritual care available either through organizational spiritual counseling or through the patient's own clergy relationships.

PREFERRED PRACTICE 22

Specialized palliative and hospice care teams should include spiritual care professionals appropriately trained and certified in palliative care.

\section{PREFERRED PRACTICE 23}

Specialized palliative and hospice spiritual care professional should build partnerships with community clergy and provide education and counseling related to end-oflife care. of philosophical, religious, spiritual, and existential issues that arise in the clinical setting. These elements were grounded in theological, philosophical, empirical, and clinical literature. $^{25,26}$ The agreed upon definition is as follows:

Spirituality is the aspect of humanity that refers to the way individuals seek and express meaning and purpose and the way they experience their connectedness to the moment, to self, to others, to nature, and to the significant or sacred.

The participants then reviewed the Consensus Document considering their work from the previous day. Participants were asked to identify areas in the document that were missing or required further elaboration or clarification and, once again, to comment on all aspects of the document. Verbal and written comments were collected.
Over the following 2 months this Consensus Document was revised yet again to incorporate the feedback from conference participants. This version of the document was sent to a panel of 150 expert reviewers for additional comments. All participants of the Consensus Conference and the 6 project advisors have reviewed this Consensus Report and agreed to its content.

\section{Conference Recommendations}

Recommendations for improving spiritual care are divided into seven keys areas that were developed from the original five focus groups from the Consensus Conference. The seven areas are

- Spiritual Care Models

- Spiritual Assessment 
Table 2. Consensus Conference Leaders and Participants

City of Hope National Medical Center, Duarte, CA

Betty R. Ferrell, Ph.D., FAAN, M.A., FPCN

Principal Investigator

Research Scientist

Rose Virani, R.N.C., M.H.A., O.C.N., ${ }^{\circledR}$ FPCN

Project Director

Senior Research Specialist

Rev. Cassie McCarty, M.Div., B.C.C.

Spiritual Care Consultant

Andrea Garcia, B.A.

Project Coordinator

George Washington Institute for Spirituality and Health,

The George Washington University, Washington, D.C.

Christina Puchalski, M.D., M.S., FACP

Co-Principal Investigator

Professor, Department of Medicine and Health Science

Executive Director

Mikhail Kogan, M.D.

Coeditor, The Spirituality and Health Online

Education and Resource Center (SOERCE)

Assistant Professor

Harvey Chochinov, M.D., Ph.D., FRCPC

Professor of Psychiatry

Cancer Care Manitoba

Winnipeg, MB, Canada

Holly Nelson-Becker, M.S.W., Ph.D.

Associate Professor

University of Kansas

Lawrence, KS

Karen Pugliese, M.A., BCC

Chaplain

Central DuPage Hospital

Winfield, IL

Joseph F. Prevratil, JD

President \& CEO

E. Thomas Brewer, M.S.W., M.P.H., M.B.A.

Director of Programs

Laura Giles, M.S.G.

Program Officer

M. Brownell "Brownie" Anderson, M.Ed.

Senior Director, Educational Affairs

Association of American Medical Colleges

Washington, D.C.

Sandra Alvarez, M.D., FAAFP

Family Physician

Elder Health Care of Volusia

DeLand, FL

Tami Borneman, R.N., M.S.N., C.N.S., FPCN

Senior Research Specialist

City of Hope

Duarte, CA
The Project Team

Shirley Otis-Green, M.S.W., L.C.S.W., A.C.S.W., O.S.W.-C. Senior Research Specialist

Rev. Pam Baird

Spiritual Care Consultant
Laurie Lyons, M.A.

Instructional Designer, The Spirituality and Health Online Education and Resource Center (SOERCE)

Janet Bull, M.A.

Associate Director

Advisors

George Handzo, M.Div., BCC, M.A.

Vice President, Pastoral Care Leadership \& Practice

HealthCare Chaplaincy

New York, NY

Maryjo Prince-Paul, Ph.D., A.P.R.N., A.C.H.P.N.

Assistant Professor

Frances Payne Bolton School of Nursing

Case Western Reserve University

Cleveland, $\mathrm{OH}$

Daniel Sulmasy, O.F.M., M.D., Ph.D.

Professor of Medicine and Medical Ethics

Schools of Medicine and Divinity

University of Chicago

Chicago, IL

For the Archstone Foundation

Mary Ellen Kullman, M.P.H.

Vice President

Elyse Salend, M.S.W.

Program Officer

Tanisha Metoyer, M.A.G.

Program Associate

Connie Peña

Executive Assistant

Facilitator

Consensus Conference Participants

Lodovico Balducci, M.D.

Professor of Oncology and Medicine

H. Lee Moffitt Cancer Center \& Research Institute

Tampa, FL

William Breitbart, M.D.

Professor and Chief of Psychiatry Service

Memorial Sloan-Kettering Cancer Center

New York, NY 
Table 2. Continued

Katherine Brown- Saltzman, R.N., M.A.

Codirector Ethics Center

The University of California Los Angeles

Health System Ethics Center

Los Angeles, CA

Ed Canda, M.A., M.S.W., Ph.D.

Professor

The University of Kansas

Lawrence, KS

Rev. Kenneth J. Doka, Ph.D.

Professor, Graduate Gerontology Program

The College of New Rochelle

New Rochelle, NY

James Duffy, M.D.

Professor of Psychiatry

University of Texas MD Anderson Cancer Center

Houston, TX

George Fitchett, D.Min., Ph.D.

Associate Professor and Director of Research

Rush University Medical Center

Chicago, IL

Roshi Joan Halifax, Ph.D.

Buddhist Teacher, Zen Priest \& Anthropologist

Upaya Zen Center

Santa Fe, NM

Carolyn Jacobs, M.S.W., Ph.D.

Dean and Elizabeth Marting Treuhaft Professor

Smith College School of Social Work

North Hampton, MA

Betty Kramer, Ph.D., M.S.W.

Professor, School of Social Work

University of Wisconsin-Madison

Madison, WI

Diane Kreslins, BCC

Oncology Spiritual Care Coordinator

Lacks Cancer Center at Saint Mary's Health Care

Grand Rapids, MI

Ellen G. Levine, Ph.D., M.P.H.

Senior Scientist

San Francisco State University

San Francisco, CA

Brother Felipe Martinez, B.A., M.Div., BCC

Roman Catholic Chaplain

Good Samaritan Hospital

Los Angeles, CA

Kristen L. Mauk, Ph.D., R.N., CRRN-A, GCNS-BC

Professor and Kreft Chair, Nursing

Valparaiso University

Valparaiso, IN

Rev. Cecil "Chip" Murray

Pastor Retired, Senior Fellow

Center for Religion

University of Southern California

Los Angeles, CA

Rev. Sarah W. Nichols, M.Div.

Director of Pastoral Care

The Episcopal Home Communities

Los Angeles, CA
Jacqueline Rene Cameron, M.Div., M.D.

Episcopal Priest and Attending Physician

St. Joseph's Hospital

Chicago, IL

Carlyle Coash, M.A., BCC

Chaplain

National Council of Hospice and Palliative Care

Professionals Section Leader for Spiritual Care

Zen Hospice Project

San Francisco, CA

Rabbi Elliot Dorff, Ph.D.

Professor in Philosophy

American Jewish University

Los Angeles, CA

Liz Budd Ellmann, M.Div.

Executive Director

Spiritual Directors International

Bellevue, WA

Gregory Fricchione, M.D.

Associate Chief of Psychiatry, Director, Professor

Massachusetts General Hospital

Boston, MA

Misha Kogan, M.D.

Assistant Professor of Geriatrics and Palliative Care George Washington University

Washington, D.C.

Mary Jo Kreitzer, Ph.D., R.N., FAAN

Director, Center for Spirituality and Healing

Professor

University of Minnesota School of Nursing

Minneapolis, MN

Judy Lentz, R.N., M.S.N., N.H.A.

Chief Executive Officer

Hospice and Palliative Nursing Association

Pittsburgh, PA

Francis Lu, M.D.

Professor of Clinical Psychiatry

University of California San Francisco

Department of Psychiatry

San Francisco, CA

Rev. Dr. James Nelson, Ph.D.

Senior Minister

Neighborhood Unitarian Universalist Church

Pasadena, CA

Steven Pantilat, M.D.

Professor of Clinical Medicine

University of California San Francisco

San Francisco, CA

Michael Rabow, M.D., FAAHPM

Associate Professor of Clinical Medicine

University of California San Francisco/Mount Zion

San Francisco, CA

M. Kay Sandor, Ph.D., R.N., L.P.C., A.H.N.-B.C.

Associate Professor

The University of Texas Medical Branch

Galveston, TX 
TABle 2. Continued

Tina Picchi, M.A., BCC

Director Palliative Care Services

St. John's Regional Medical Center

Oxnard, CA

Daniel Robitshek, M.D.

Professor of Medicine

UC Irvine School of Medicine

Orange, CA

Rev. William E. Scrivener, BCC

Senior Director, Dept. of Pastoral Care

Children's Hospital Medical Center.

Cincinnati, $\mathrm{OH}$

Sharon Stanton, M.S., B.S.N., R.N.

President

Health Ministries Association, Inc.

Queen Creek, AZ
Karen Skalla, M.S.N., A.R.N.P., A.O.C.N. ${ }^{\circledR}$

Oncology Nurse Practitioner

Dartmouth Hitchcock Medical Center.

Lebanon, $\mathrm{NH}$

Alessandra Strada, Ph.D.

Attending Psychologist

Beth Israel Medical Center

New York, NY

Jeanne Twohig, M.P.A.

Deputy Director

Duke Institute on Care at the End of Life

Durham, NC
- Spiritual Treatment/Care Plans

- Interprofessional Team

- Training/Certification

- Personal and Professional Development

- Quality Improvement

\section{Spiritual Care Models}

Spiritual care models offer a framework for health care professionals to connect with their patients; listen to their fears, dreams, and pain; collaborate with their patients as partners in their care; and provide, through the therapeutic relationship, an opportunity for healing. Healing is distinguished from cure in this context. It refers to the ability of a person to find solace, comfort, connection, meaning, and purpose in the midst of suffering, disarray, and pain. The care is rooted in spirituality using compassion, hopefulness, and the recognition that, although a person's life may be limited or no longer socially productive, it remains full of possibility. ${ }^{27}$

Spiritual care is grounded in important theoretical frameworks, one of which is the Biopsychosocial-Spiritual Model of Care. ${ }^{28,29}$ Another is a patient-centered care model in which the focus of care is on the patient and his or her experience of illness as opposed to a sole focus on the disease. ${ }^{30}$ Integral to both of these models is the recognition that there is more to the care of the patient than the physical.

\section{Biopsychosocial-spiritual model of care}

The work of Engel ${ }^{31}$ and White ${ }^{32}$ proposed a biopsychosocial model for care that can readily be extended to encompass the spiritual ${ }^{29}$ (Fig. 1). This approach is based on a philosophical anthropology, a cornerstone of which is the concept of the person as a being-in-relationship. Jonas ${ }^{33}$ said, "Life is essentially relationship; and relation as such implies 'transcendence,' a going-beyond-itself on the part of that which entertains the relation." Disease can be understood as a disturbance in the right relationships that constitute the unity and integrity of what we know to be a human being. Humans are intrinsically spiritual since all persons are in relationship with themselves, others, nature, and the significant or sacred.
To know a thing is to grasp the complex set of relationships that define it, whether that thing is a quark or a human being. ${ }^{34}$ This is especially true of living things.

Contemporary scientific healing retains the same formal structure that informed prescientific cultures-healing is still about the restoration of right relationships. Illness disturbs more than relationships inside the human organism; it disrupts families and workplaces, shatters preexisting patterns of coping, and raises questions about one's relationship with the significant or the sacred. ${ }^{29}$ According to the biopsychosocialspiritual model, everyone has a spiritual history. For many people, this spiritual history unfolds within the context of an explicit religious tradition; for others it unfolds as a set of philosophical principles or significant experiences. Regardless, this spiritual history helps shape who each patient is as a whole person. When life-threatening illness strikes, it strikes each person in his or her totality. ${ }^{35}$ This totality includes not simply the biologic, psychological, and social aspects of the person, ${ }^{36}$ but also the spiritual aspects as well. ${ }^{37,38}$ The biologic, psychological, social, and spiritual are distinct dimensions of each person. No one aspect can be disaggregated from the whole. Each aspect can be affected differently by a person's history and illness and each aspect can interact and affect other aspects of the person.

\section{Interprofessional spiritual care model}

The spiritual care model that underpinned the work of the Consensus Conference is a relational model in which the patient and clinicians work together in a process of discovery, collaborative dialogue, treatment and ongoing evaluation, and follow-up. The model, developed prior to the conference and then presented and discussed at the conference and subsequently modified, is different for inpatient (Fig. 2) and outpatient (Fig. 3) settings but the overall goals are similar. All parties in the spiritual care model have the potential for being transformed by interaction with one another. Based on examples in the literature ${ }^{39-41}$ and the input from consensus participants and advisors, a model was developed for implementing spiritual care. Health care professionals should 


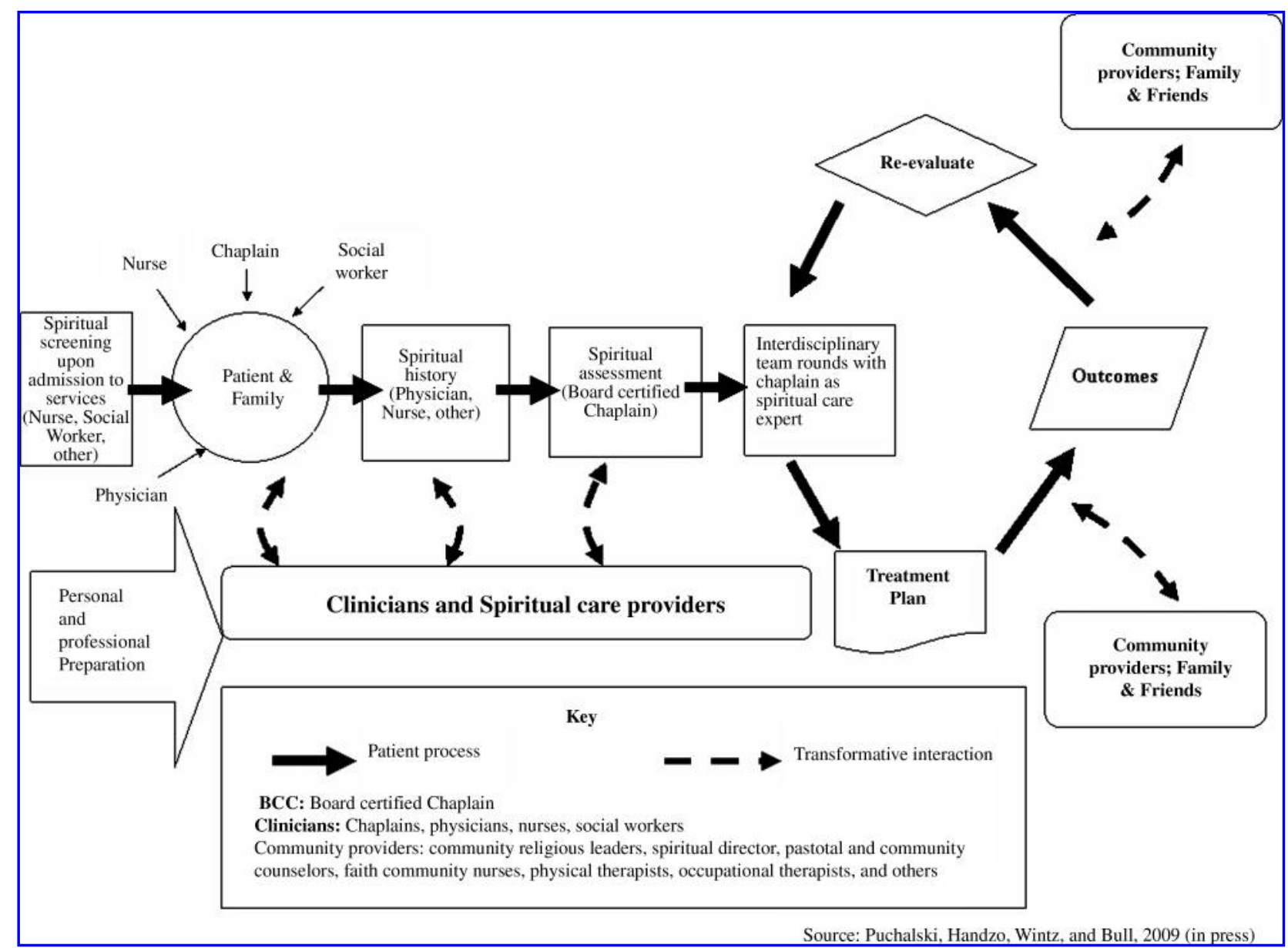

FIG. 1. Inpatient spiritual care implementation model.

take an appropriate spiritual history from the patient upon admission to the clinical setting. Based on information from the spiritual history, clinicians can identify the presence of a spiritual issue (including spiritual distress or spiritual resources of strength) and make the appropriate referrals to chaplains in the inpatient setting or to other appropriate spiritual care providers in an outpatient setting. Clinicians should distinguish when the patient presents with emotional or psychosocial issues, spiritual issues, or both and make the appropriate referral. This model is based on a generalistspecialist model of care in which board-certified chaplains are considered the trained spiritual care specialists. These boardcertified chaplains serve as a resource to identify other spiritual care providers who might be appropriate for the patient.

\section{Recommendations}

1. Spiritual care should be integral to any compassionate and patient-centered health care system model of care.

2. Spiritual care models should be based on honoring the dignity of all people and on providing compassionate care.

3. Spiritual distress or religious struggle should be treated with the same intent and urgency as treatment for pain or any other medical or social problem.

4. Spirituality should be considered a patient vital sign. Just as pain is screened routinely, so should spiritual issues be a part of routine care. Institutional policies for spiritual history and screening must be integrated into intake policies and ongoing assessment of care.

5. Spiritual care models should be interdisciplinary and clinical settings should have a Clinical Pastoral Educationtrained board-certified chaplain as part of the interprofessional team.

\section{Spiritual Assessment of Patients and Families}

Failure to assess spiritual needs may potentially neglect an important patient need; it also fails to consider patients as whole persons. Communication with patients and families about spiritual issues ranges from preliminary screening in order to identify potential spiritual issues to a spiritual history taken by trained health care providers to a spiritual assessment by a board-certified chaplain. ${ }^{42,43}$

\section{Spiritual screening}

Spiritual screening or triage is a quick determination of whether a person is experiencing a serious spiritual crisis and therefore needs an immediate referral to a board-certified chaplain. Spiritual screening helps identify which patients may benefit from an in-depth spiritual assessment. Good models of spiritual screening use a few simple questions that can be asked in the course of an overall patient and family screening. Examples of such questions include, "Are spirituality or religion 


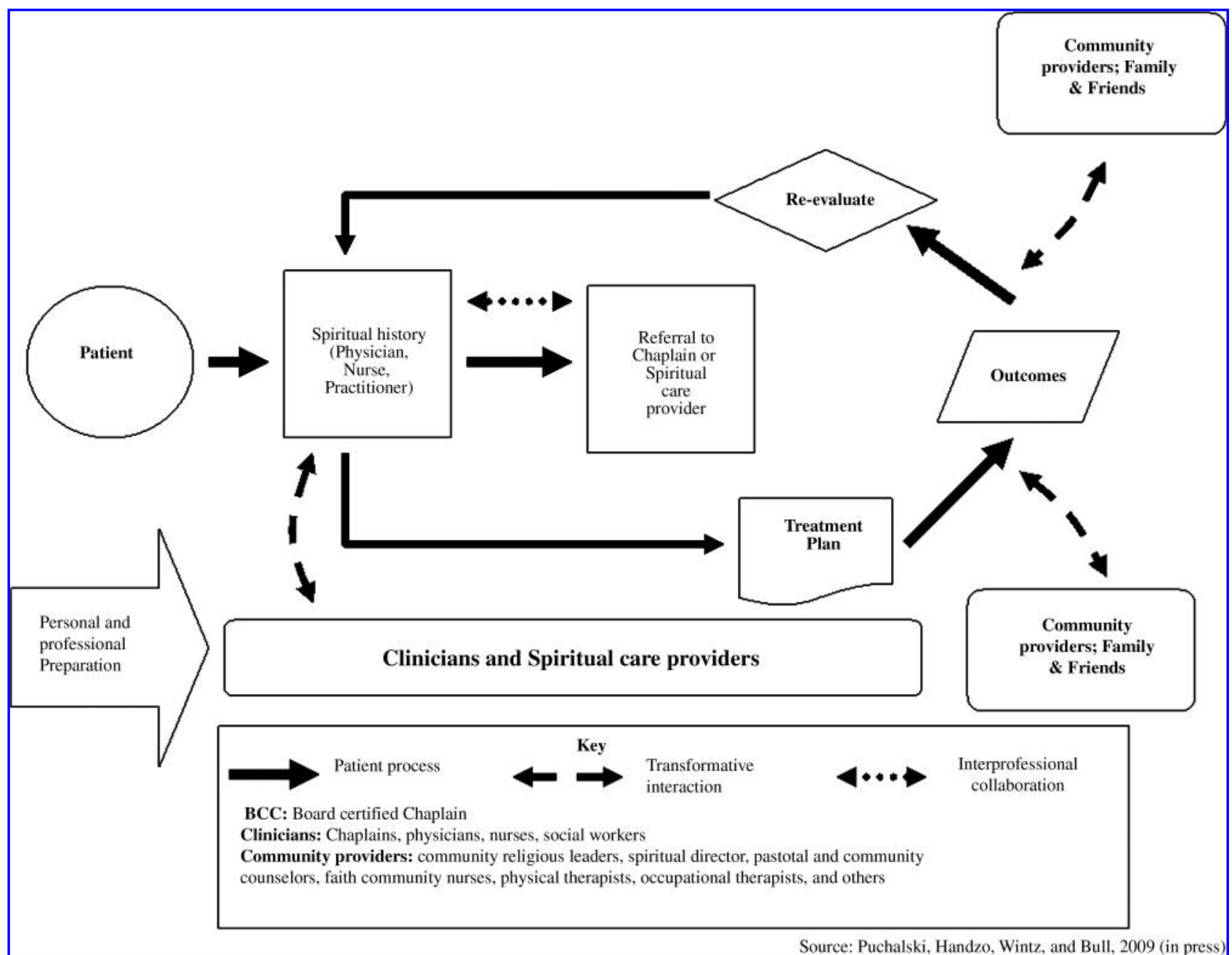

FIG. 2. Outpatient spiritual care implementation model.

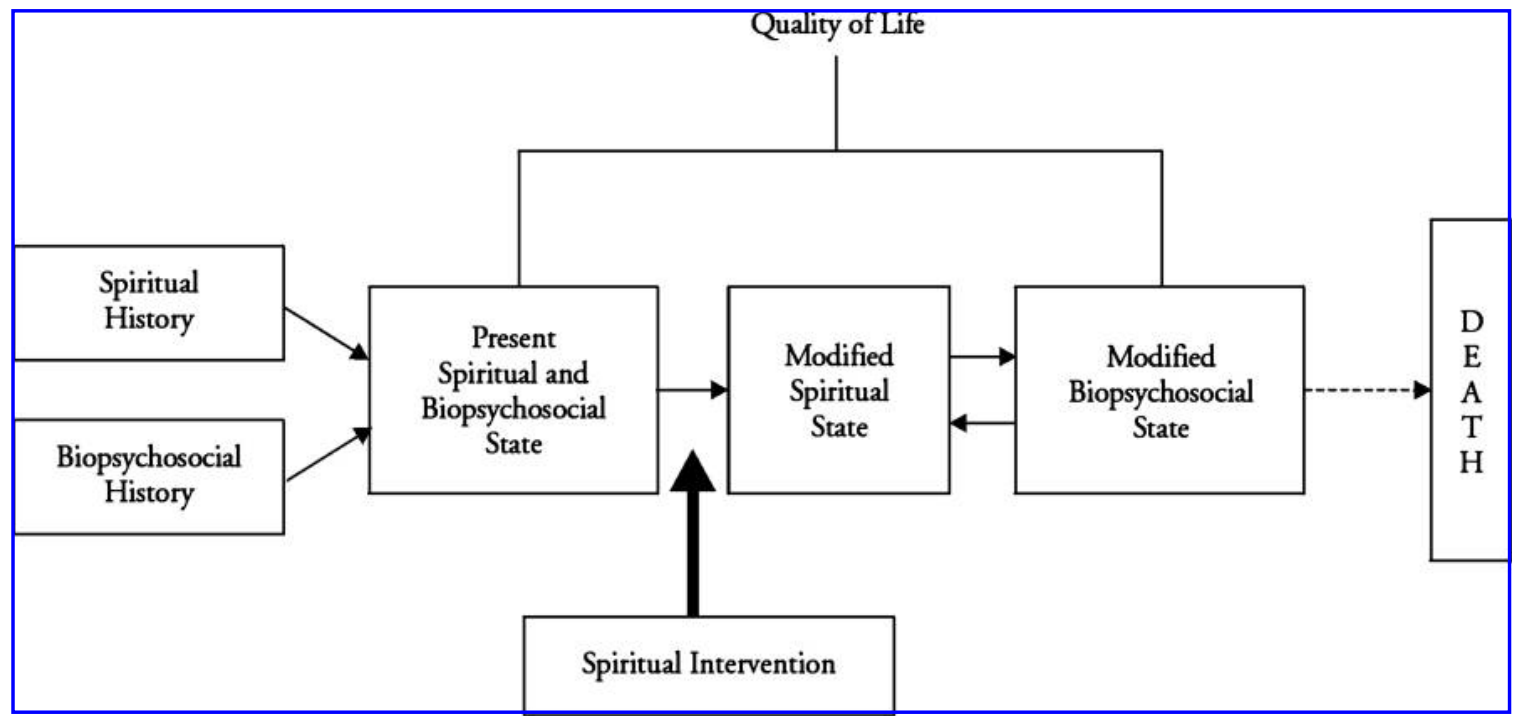

FIG. 3. The biopsychosocial-spiritual model of care. From Sulmasy DP: A biophysical-spiritual model for the care of patients at the end of life. Gerontologist 2002;42(Spec 3):24-33. Used with permission. 
important in your life?" and "How well are those resources working for you at this time?"

\section{Spiritual history}

Spiritual history-taking is the process of interviewing a patient in order to come to a better understanding of their spiritual needs and resources. A spiritual history can be integrated into existing formats such as the social history section of the clinical database. Compared to screening, history-taking uses a broader set of questions to capture salient information about needs, hopes, and resources. The history questions are asked in the context of a comprehensive examination by the clinician who is responsible for providing direct care or referrals to specialists. The information from the history permits the clinician to understand how spiritual concerns could either complement or complicate the patient's overall care. It also allows the clinician to incorporate spiritual care into the patient's overall care plan. Unlike spiritual screening, which requires only brief training, those doing a spiritual history should have some education in and comfort with issues that may emerge and knowledge of how to engage patients comfortably in this discussion.

The goals of the spiritual history are to

- Invite all patients to share spiritual and religious beliefs, and to define what spirituality is for them and their spiritual goals.

- Learn about the patient's beliefs and values.

- Assess for spiritual distress (meaninglessness, hopelessness) as well as for sources of spiritual strength (hope, meaning, and purpose).

- Provide an opportunity for compassionate care.

- Empower the patient to find inner resources of healing and acceptance.

- Identify spiritual and religious beliefs that might affect the patient's health care decision-making.

- Identify spiritual practices that might be helpful in the treatment or care plan.

- Identify patients who need referral to a board-certified chaplain or other equivalently prepared spiritual care provider.

There are clinical history tools available that can be used to collect and document clinical information. Several tools have been developed for this purpose including FICA (Faith/ Beliefs, Importance, Community, Address in care or action), ${ }^{41,43}$ SPIRIT (Spiritual belief system, Personal Spirituality, Integration, Rituals/restrictions, Implications, and Terminal events), ${ }^{40}$ HOPE (Hope, Organized religion, Personal spirituality, Effects of care and decisions), ${ }^{39}$ and Domains of Spirituality (developed for use by social workers). ${ }^{44}$ Generally, these tools include more objective data (e.g., religious affiliation, spiritual practices) while touching upon deeper and more subjective spiritual aspects (e.g., meaning, importance of belief, sources of hope).

\section{Spiritual assessment}

Formal spiritual assessment refers to a more extensive process of active listening to a patient's story conducted by a board-certified chaplain that summarizes the needs and resources that emerge in that process. The chaplain's summary should include a spiritual care plan with expected outcomes that is then communicated to the rest of the treatment team. Unlike history-taking, the major models for spiritual assessment are not built on a set of questions that can be used in an interview. Rather, the models are interpretive frameworks that are based on listening to the patient's story as it unfolds. Because of the complex nature of these assessments and the special clinical training necessary to engage in them, this assessment should be done only by a board-certified chaplain or an equivalently prepared spiritual care provider.

When each level of evaluation occurs depends on the setting and who is asking the questions. In hospitals, nursing homes, or hospices, spiritual screening should be done by the nurse or social worker upon triage or admission in order to assess for spiritual emergencies that may require immediate intervention. In outpatient settings, a spiritual screening might not take place as an event separate from the clinical encounter. Rather, if the patient comes to the physician's office in distress, a spiritual screening might be done as part of the initial conversation with the physician, advanced practice nurse, or physician assistant. A spiritual history could be done by the physician, nurse, social worker, or other clinician responsible for developing and assessment and treatment plan. The spiritual assessment would be done by a board-certified chaplain.

\section{Recommendations}

1. All patients should receive a simple and time-efficient spiritual screening at the point of entry into the health care system and appropriate referrals as needed.

2. Health care providers should adopt and implement structured assessment tools to facilitate documentation of needs and evaluation of outcomes of treatment.

3. All staff members should be vigilant, sensitive, and trained to recognize spiritual distress.

4. All health care professionals should be trained in doing a spiritual screening or history as part of their routine history and evaluation; unlicensed staff members should report all witnessed pain or spiritual distress.

5. Formal spiritual assessments should be made by a board-certified chaplain who should document their assessment and communicate with the referring provider about their assessment and the plans of care.

6. Spiritual screenings, histories, and assessments should be communicated and documented in patient records (e.g., charts, computerized databases, and shared during interprofessional rounds). Documentation should be placed in a centralized location for use by all clinicians. If a computerized patient database is available, spiritual histories and assessments should be included.

7. Follow-up spiritual histories or assessments should be conducted for all patients whose medical, psychosocial, or spiritual condition changes and as part of routine follow-up in a medical history.

8. The chaplain should respond within 24 hours to a referral for spiritual assessment.

\section{Formulation of a Spiritual Treatment Plan}

\section{Integrating spiritual issues into the treatment plan}

Health care professionals determine how to integrate information from the spiritual assessment into the patient's 
TAble 3. Spiritual Concerns

\begin{tabular}{|c|c|c|}
\hline Diagnoses (Primary) & Key feature from history & Example statements \\
\hline Existential concerns & $\begin{array}{l}\text { Lack of meaning } \\
\text { Questions meaning about one's } \\
\text { own existence } \\
\text { Concern about afterlife } \\
\text { Questions the meaning of suffering } \\
\text { Seeks spiritual assistance }\end{array}$ & $\begin{array}{l}\text { "My life is meaningless." } \\
\text { "I feel useless." }\end{array}$ \\
\hline $\begin{array}{l}\text { Abandonment by God } \\
\text { or others }\end{array}$ & $\begin{array}{l}\text { Lack of love, loneliness } \\
\text { Not being remembered } \\
\text { No sense of Relatedness }\end{array}$ & $\begin{array}{l}\text { "God has abandoned me." } \\
\text { "No one comes by anymore." }\end{array}$ \\
\hline Anger at God or others & $\begin{array}{l}\text { Displaces anger toward religious } \\
\text { representatives } \\
\text { Inability to forgive }\end{array}$ & $\begin{array}{l}\text { "Why would God take } \\
\text { my child. . . it's not fair." }\end{array}$ \\
\hline $\begin{array}{l}\text { Concerns about relationship } \\
\text { with deity }\end{array}$ & $\begin{array}{l}\text { Desires closeness to God, } \\
\text { deepening relationship }\end{array}$ & $\begin{array}{l}\text { "I want to have a deeper } \\
\text { relationship with God." }\end{array}$ \\
\hline $\begin{array}{l}\text { Conflicted or challenged } \\
\text { belief systems }\end{array}$ & $\begin{array}{l}\text { Verbalizes inner conflicts or questions } \\
\text { about beliefs or faith } \\
\text { Conflicts between religious beliefs } \\
\text { and recommended treatments } \\
\text { Questions moral or ethical implications } \\
\text { of therapeutic regimen } \\
\text { Expresses concern with life/death } \\
\text { or belief system }\end{array}$ & $\begin{array}{l}\text { "I am not sure if God is } \\
\text { with me anymore." }\end{array}$ \\
\hline Despair/Hopelessness & $\begin{array}{l}\text { Hopelessness about future health, life } \\
\text { Despair as absolute hopelessness } \\
\text { No hope for value in life }\end{array}$ & $\begin{array}{l}\text { "Life is being cut short." } \\
\text { "There is nothing left } \\
\text { for me to live for." }\end{array}$ \\
\hline Grief/loss & $\begin{array}{l}\text { The feeling and process associated with } \\
\text { the loss of a person, health, relationship }\end{array}$ & $\begin{array}{l}\text { "I miss my loved one so much." } \\
\text { "I wish I could run again." }\end{array}$ \\
\hline Guilt/shame & $\begin{array}{l}\text { Feeling that one has done something } \\
\text { wrong or evil } \\
\text { Feeling that one is bad or evil }\end{array}$ & "I do not deserve to die pain-free." \\
\hline Reconciliation & $\begin{array}{l}\text { Need for forgiveness or reconciliation } \\
\text { from self or others }\end{array}$ & $\begin{array}{l}\text { "I need to be forgiven for what I did." } \\
\text { "I would like my wife to forgive me." }\end{array}$ \\
\hline Isolation & $\begin{array}{l}\text { Separated from religious } \\
\text { community or other }\end{array}$ & $\begin{array}{l}\text { "Since moving to the assisted } \\
\text { living I am not able to go to } \\
\text { my church anymore." }\end{array}$ \\
\hline Religious-specific & $\begin{array}{l}\text { Ritual needs } \\
\text { Unable to perform usual religious practices }\end{array}$ & "I just can't pray anymore." \\
\hline Religious/spiritual struggle & $\begin{array}{l}\text { Loss of faith or meaning } \\
\text { Religious or spiritual beliefs or community } \\
\text { not helping with coping }\end{array}$ & $\begin{array}{l}\text { "What if all that I believe } \\
\text { is not true." }\end{array}$ \\
\hline
\end{tabular}

overall treatment plan. Using the language consistent with practice in most health care settings, this includes identifying or diagnosing the spiritual problems/needs; identifying spiritual goals (if appropriate); and determining, implementing, and evaluating the appropriate spiritual interventions (Tables 3 and 4). Health care professionals involved in assessing and referring patients should identify spiritual issues or make spiritual diagnoses if applicable. Some spiritual diagnosis labels currently exist but these may be limited in scope (e.g., to patients with cancer) and also are not presently used for reimbursement. Thus a clinician may identify a spiritual issue or a patient's sources of strength or the clinician may identify a spiritual diagnosis. In general a spiritual issue becomes a diagnosis if the following criteria are met:

1. The spiritual issue leads to distress or suffering (e.g., lack of meaning, conflicted religious beliefs, inability to forgive).

2. The spiritual issue is the cause of a psychological or physical diagnosis such as depression, anxiety, or acute or chronic pain (e.g., severe meaninglessness that leads to depression or suicidality, guilt that leads to chronic physical pain).

3. The spiritual issue is a secondary cause or affects the presenting psychological or physical diagnosis (e.g., hypertension is difficult to control because the patient refuses to take medications because of his or her religious beliefs).

If there is an interprofessional team involved then a boardcertified chaplain, as the expert in spiritual care, provides the input and guidance as to the diagnosis and treatment plan with respect to spirituality. In situations were there is no interprofessional team, health care professionals identify the issues or make the diagnoses and develop the treatment plan. These clinicians are responsible for referring complex spiritual issues to a board-certified chaplain. For simple issues, such as a patient wanting to learn about yoga, meditation, or art or music therapy, the health care professional can make the appropriate referral or implement a course of action. For 


\section{Therapeutic communication techniques}

Therapy

Self-care
1. Compassionate presence

2. Reflective listening, query about important life events

3. Support patient's sources of spiritual strength

4. Open-ended questions to illicit feelings

5. Inquiry about spiritual beliefs, values and practices

6. Life review, listening to the patient's story

7. Continued presence and follow-up

8. Guided visualization for "meaningless pain"

9. Progressive relaxation

10. Breathing practice or contemplation

11. Meaning-oriented therapy

12. Referral to spiritual care provider as indicated

13. Use of story telling

14. Dignity-conserving therapy

15. Massage

16. Reconciliation with self or others

17. Spiritual support groups

18. Meditation

19. Sacred/spiritual readings or rituals

20. Yoga, tai chi

21. Exercise

22. Art therapy (music, art, dance)

23. Journaling the more complex spiritual issues, referral to a board-certified chaplain or other spiritual care provider is critical. Use of decision tree algorithms may facilitate the care process. Figure 4 is an example of one such algorithm.

Several surveys have demonstrated that some patients would like to be able to pray with their physicians and nurses. ${ }^{45,46}$ A survey conducted by Stanford University Medical Center, ABC News, and USA Today in $2005^{47}$ reported that prayer is the second most commonly used method that hospitalized patients rely upon for pain control, after opioid analgesics. Astrow ${ }^{1}$ and $\mathrm{Lo}^{48}$ have developed guidelines for praying with patients that could be adapted a priori. Regardless, prayer requests from patients should be handled sensitively and compassionately.

Tables 5 and 6 are examples of how spiritual care can be incorporated into a treatment plan. These plans should include input from the interprofessional team and be updated on a regular basis based on appropriate follow-up and reevaluation.

\section{Evaluation and follow-up}

NCP Guidelines ${ }^{21}$ call for periodic reevaluation of the impact of spiritual/existential interventions and patient and family preferences. Any time a diagnosis of a spiritual nature is made or a need is identified, whether related to pain, nutrition or a psychosocial or spiritual distress, it is of utmost importance to determine the impact of the interventions and adjust the plan of care as needed. ${ }^{49}$

\section{Documentation}

Documenting the provision of spiritual care allows for communication about the intervention and the corresponding desired outcomes. Documentation should occur in the social history section of the intake history and physical of the patient's chart, as well as in the daily progress notes as applica- ble. Documentation of the intervention showing its value and effectiveness is key to quality care and provides knowledge to other members of the interprofessional team who share in the care of the patient. Health care professionals could consider documenting spiritual issues as part of a comprehensive biopsychosocial-spiritual assessment and plan. Sound clinical judgment should govern how much detail is provided in the documentation. Private content or information offered in confidence should be documented only to the extent that it directly affects the patient's clinical care of patients and is critical for other members of the interprofessional team to know.

\section{Recommendations}

1. Screen and assess every patient's spiritual symptoms, values, and beliefs and integrate them into the plan of care.

2. All trained health care professionals should do spiritual screening and history-taking. These caregivers should also identify any spiritual diagnoses and develop a plan of care. Detailed assessment and complex diagnosis and treatment are the purview of the board-certified chaplains working with the interprofessional team as the spiritual care experts.

3. Currently available diagnostic labels (e.g., National Comprehensive Cancer Network [NCCN] Distress Management guidelines, ${ }^{50}$ Diagnostic and Statistical Manual [DSM] code V62.89, ${ }^{51}$ NANDA nursing diagnoses ${ }^{52}$ ) can be used, but further work is needed to develop more comprehensive diagnostic codes for spiritual problems.

4. Treatment plans should include but not be limited to: a. Referral to chaplains, spiritual directors, pastoral counselors, and other spiritual care providers including clergy or faith-community healers for spiritual counseling 


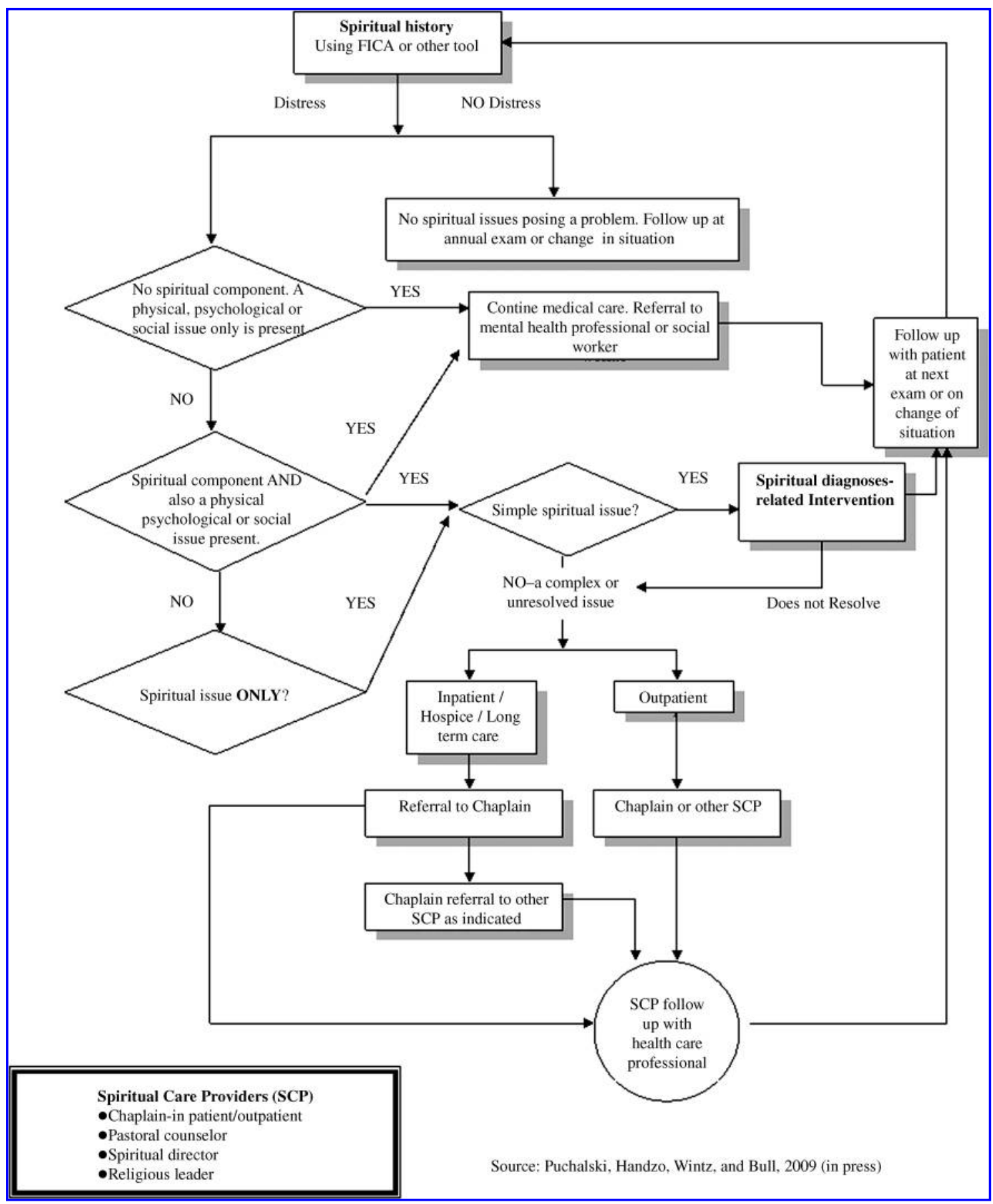

FIG. 4. Spiritual diagnosis decision pathways.

b. Development of spiritual goals

c. Meaning-oriented therapy

d. Mind-body interventions

e. Rituals, spiritual practices

f. Contemplative interventions

5. Patients should be encouraged and supported in the expression of their spiritual needs and beliefs as they desire and this should be integrated into the treatment or care plan and reassessed periodically. Written material regarding spiritual care, including a description of the role of chaplains should be made available to patients and families. Family and patient requests specifically related to desired rituals at any point in their care and particularly at the time of death should be honored.

6. Board-certified chaplains should function as spiritual care coordinators and help facilitate appropriate referrals to other spiritual care providers or spiritual therapies (e.g., meditation training) as needed.

7. Spiritual support resources from the patient's own spiritual/religious community should be noted in the chart. 
Table 5. Case Example: Assessment and Treatment Plan

An 80-year-old man dying of end-stage colon cancer with well-controlled pain, some anxiety, unresolved family issues, and fear about dying.

\begin{tabular}{|c|c|c|}
\hline Dimension & Assessment & Plan \\
\hline \multirow[t]{2}{*}{ Physical } & Well-controlled pain & Continue current medication regimen. \\
\hline & $\begin{array}{l}\text { Nausea and vomiting, likely secondary } \\
\text { to partial small bowel obstruction. }\end{array}$ & $\begin{array}{l}\text { Evaluate treatment options to relieve } \\
\text { nausea associated with bowel } \\
\text { obstruction. }\end{array}$ \\
\hline \multirow[t]{2}{*}{ Emotional } & $\begin{array}{l}\text { Anxiety about dyspnea that may } \\
\text { be associated with dying }\end{array}$ & $\begin{array}{l}\text { Refer to counselor for anxiety } \\
\text { management and exploration of } \\
\text { issues about fear of dying. }\end{array}$ \\
\hline & Anxiety affecting sleep at night & $\begin{array}{l}\text { Consult with palliative care service } \\
\text { for treatment of dyspnea and anxiety. }\end{array}$ \\
\hline Social & $\begin{array}{l}\text { Unresolved issues with family members } \\
\text { as well as questions about funeral } \\
\text { planning and costs }\end{array}$ & $\begin{array}{l}\text { Refer to social worker for possible } \\
\text { family intervention as well as } \\
\text { assistance with end-of-life planning. }\end{array}$ \\
\hline Spiritual & $\begin{array}{l}\text { Expresses fear about dying; } \\
\text { seeks forgiveness from son for being a } \\
\text { "distant dad." }\end{array}$ & $\begin{array}{l}\text { Refer to chaplain for spiritual } \\
\text { counseling, consider forgiveness } \\
\text { intervention, encourage discussion } \\
\text { about fear of death } \\
\text { Continue presence and support. }\end{array}$ \\
\hline
\end{tabular}

8. Follow-up evaluations should be done regularly, especially when there is a change in status or level of care, or when a new diagnosis or prognosis is determined.

9. Treatment algorithms can be useful adjuncts to determine appropriate interventions.

10. The discharge plan of care should include all dimensions of care, including spiritual needs.

11. Spiritual care must extend to bereavement care. Palliative care programs should institute processes to ensure that systematic bereavement support is provided. Referral to bereavement counselors or services should be available as appropriate for loved ones and families after the death of the patient. Structured bereavement assessment tools should be used to identify needs for support and those at greatest risk for complicated grief.

12. Health care professionals should establish procedures for contact with family or loved ones following the death of a patient. This may include sending condolences, attending funerals, holding memorial services, or other rituals to offer support to and connection with to the family.

\section{Interprofessional Considerations: Roles and Team Functioning}

Collaboration among the members of interprofessional teams has become a central component in health care delivery

Table 6. Case Example: Discharge Plan

A 65-year-old woman admitted for repair of hip fracture; surgery went well, without complications.

Now being discharged to a rehabilitation facility. Noted anxiety, separation from religious community.

Has strong spiritual beliefs, good level of hope, strong family support. Her spiritual goals include deepening her relationship with God. Expressed interest in learning meditation.

\begin{tabular}{|c|c|c|}
\hline Domain & Problem & Plan \\
\hline Physical & Status post-hip fracture & $\begin{array}{l}\text { Physical and occupational therapy } \\
\text { Ensure adequate pain management }\end{array}$ \\
\hline Emotional & $\begin{array}{l}\text { Anxious about not being able to work; } \\
\text { has panic attacks at night }\end{array}$ & $\begin{array}{l}\text { Evaluate options to treat anxiety and sleeplessness } \\
\text { Counseling with social worker }\end{array}$ \\
\hline Social & Isolation in new facility & $\begin{array}{l}\text { Encourage family to visit at new facility } \\
\text { Contact rehabilitation facility to get information } \\
\text { regarding activities, volunteers, support available }\end{array}$ \\
\hline Spiritual & $\begin{array}{l}\text { Isolation from church community; } \\
\text { desires deepening of her relationship } \\
\text { with God }\end{array}$ & $\begin{array}{l}\text { Refer to chaplain } \\
\text { Refer to spiritual director once discharged } \\
\text { from rehabilitation facility } \\
\text { Provide list of meditation centers and teachers } \\
\text { in patient's community or refer to social work for } \\
\text { basic instruction }\end{array}$ \\
\hline
\end{tabular}

Puchalski, C. (2006a). Spiritual assessment in clinical practice. Psychiatric Annals 2006;36:150. Used with permission. 
systems. ${ }^{53-56}$ No one clinician can possibly meet the combined physical, psychosocial, spiritual, and personal needs of patients. While all team members have some responsibility for spiritual care, board-certified chaplains play a key role as the team member most directly responsible for spiritual care. As The Joint Commission ${ }^{57}$ has asserted: "The emerging prominent role of clinically trained, professional board-certified chaplains working with health care organizations in completing spiritual assessments, functioning as the 'cultural broker,' and leading cultural and spiritual sensitivity assessments for staff and physicians can be of great value. Organizations that employ board-certified chaplains are able to focus directly on the significance and incorporation of cultural, spiritual, and religious practices into the plan of care." In the outpatient setting, having an interprofessional team is more challenging. Physicians and advance practice nurses can consult with social workers and outpatient chaplains or other equivalently trained spiritual care professionals.

Despite the advantages, however, interprofessional team care raises a number of issues. The team must decide how patient-care responsibilities are to be apportioned. The team leader must strike a balance between the role of "captain" and the role of facilitator or convener. Each team member must be aware of and respect the professional ethics of other team members. Any team member who cooperates in, or fails to object to, any harmful act is a moral accomplice. Team dynamics also can raise ethical issues. In the interest of harmony, team members can become too compliant or be too eager to be seen as "good team-players." It is important that all members of the interprofessional team be respected and valued as integral participants in the care of the patient. Finally, patients and family members also have roles to play as members of the palliative care team.

\section{Interprofessional communication/confidentiality and spiritual care}

Communication is a critical element of interprofessional care. Whether in the hospice, hospital, outpatient, or longterm care setting, interprofessional rounds may offer the best way to optimize communication. Documentation in the patient record is essential to communicate spiritual concerns. Practice principles are important to foster interprofessional collaborative spiritual care (Table 7).

\section{Interprofessional functioning in the outpatient setting}

Incorporation of a full interprofessional team in the outpatient setting may present challenges. There are no generally accepted guidelines or practices for spiritual care in this arena.

Table 7. Guide for Interprofessional Collaborative Spiritual Care

Preamble: The goal of this guide is to promote meaningful, compassionate care that addresses the spiritual dimension of an individual. The spiritual dimension is an essential part of the individual's personal striving for health, wholeness, and meaning of life. Each person's definition of spirituality is individualized and may or may not include a religious preference.

This is a guide to the ways in which health care professionals can honor, integrate, and bring to light the spiritual underpinnings of a wide variety of professional ethical codes for a mutual goal of achieving the highest possible level of health and healing for all.

Collaborators: Patients, families, and a variety of health and spiritual care professionals: such as health care chaplains/clergypersons/spiritual and religious leaders, culturally based healers, mind-body practitioners, nurses, physicians, psychologists, public health researchers, social workers, and community health educators.

Shared Values: Autonomy, compassion, competence, confidentiality, courage, dignity, equality, generosity, humility, integrity, justice, respect, reverence, trust, and worth.

Guiding Documents: American Psychological Association's Code of Ethics, American Medical Association's Principles of Medical Ethics, American Nurses Association's Code of Ethics, Association of Professional Chaplains Code of Ethics, National Association of Catholic Chaplains Code of Ethics, National Association of Social Workers Code of Ethics, Public Health Leadership Society's Principles of the Ethical Practice of Public Health, and the Unified Code of Ethics for Healers.

This guide affirms the following for health care professionals in the provision of spiritual care:

1. Recognize spirituality as an integral component to the human experience of illness, healing, and health.

2. Perform spiritual inquiry in a patient-centered, confidential, and respectful manner.

3. Elicit the patient's ongoing spiritual concerns/issues/needs.

4. Be sensitive to the ways in which a patient describes spiritual beliefs, practices, values, meaning, and relationships.

5. Respect patient autonomy to address or not address spirituality.

6. Practice spiritual self-care as a provider of spiritual care.

7. Collaborate with qualified interdisciplinary professionals.

8. Provide competent and compassionate spiritual care.

9. Work in partnership in the study, application, and advancement of scientific knowledge regarding spirituality and health care.

10. Perform only those services for which one is qualified, observe all laws, and uphold the dignity and honor of one's profession.

Prepared as the final class project, for Practical Tools in Spiritual Care, a course in the Online Graduate Certificate Program in Spirituality and Health, George Washington University and George Washington University Institute for Spirituality and Health, 2008, D. Kreslins, S. Alvarez-Baez, M. Hardee, M. McCahill, L.J. Peterson; C. Puchalski, M.D., Course Director. 
It is easy to assume that patients or family member who desire spiritual care or who would find it useful have access to spiritual or religious resources and a community to provide for that need. However, Balboni ${ }^{9}$ found that $49 \%$ of patients with advanced cancer were not finding their religious and spiritual needs met by their faith communities.

It is often the case that the patients and caregivers in outpatient settings will not have a regular chaplain available to them. The Joint Commission ${ }^{57}$ only requires that accredited institutions "accommodate" spiritual and religious needs. There is no requirement that a chaplain or spiritual care provider of any kind be available. Many hospitals and long-term care facilities provide for spiritual needs with volunteer community clergy or religious leaders. As more and more health care is shifted to the outpatient setting because of economics and as burdens on the health care system increase, opportunities to provide spiritual care to patients and families will increase and may also set the stage for requiring boardcertified chaplains or equivalently prepared spiritual care providers in the outpatient setting.

\section{Community spiritual leaders: Members of the team at large}

In addition to social workers, chaplains, physicians, and nurses, there are other spiritual professionals who can participate as part of the larger palliative care team. These include community clergy, religious leaders, community elders, spiritual directors, pastoral counselors, parish nurses, lay religious professionals, culturally-based healers, and other spiritual care providers of diverse religious, spiritual, and culturally diverse backgrounds including humanitistic nonreligious leaders.

When building relationships with community religious or spiritual care providers, it is important for the interprofessional health care team to determine what training the person has, since this can vary widely. It is also important to determine the person's beliefs about how medical decisions should be made and how end-of-life care should proceed, especially with regard to the use of pain medicines and life-sustaining treatments.

\section{Recommendations}

1. Policies about effective and appropriate communication channels between health care professionals and spiritual care professionals in a variety of health care settings are needed.

2. Policies should be developed by clinical sites to facilitate networking, communication, and coordination among spiritual care providers. Board-certified chaplains can function as spiritual care coordinators to facilitate this communication.

3. Health care professionals should work to create healing environments in their workplace.

4. Respect for the dignity of all health care professionals should be reflected in policies (e.g., a hospital code of ethics could include respect for fellow workers and treating all with compassion).

5. Spiritual care providers should document their assessment of patient needs in the patient record and contribute to the treatment plans as appropriate as part of interprofessional communication and collaboration.
6. Given the significant shift in health care to outpatient settings, there is a need for board-certified chaplains in these areas. Initial screening and some treatment of spiritual issues may be done by health care professionals such as physicians, counselors, parish nurses, and social workers. More complex spiritual issues need to be attended to by a board-certified chaplain or equivalently prepared spiritual care provider.

7. Activities and programs to enhance team spirit and system-wide compassion and respect can be introduced into the workplace. These can include retreats, opportunities for reflection, team-building experiences, and service recognition awards for compassionate care.

\section{Training and Certification}

Since 2000 there has been a significant increase in formal education in spirituality and health in the health care professions. Over 85\% of medical and osteopathic schools have topics related to spirituality integrated into the curriculum. ${ }^{25}$ Nursing has integrated spirituality into baccalaureate education. ${ }^{58,59}$ Social work programs have spirituality integrated into their undergraduate and masters program. ${ }^{60}$ The Marie Curie Cancer Center in London has developed a set of competencies for health care providers for spiritual care. $^{61}$

Chaplains (whether ordained, commissioned, or otherwise set aside by their religious-tradition community) are identified leaders who have acquired an extended education in pastoral care. All board-certified chaplains have at least 1600 hours of clinical pastoral education. Clinical Pastoral Education (CPE) is interfaith professional education for ministry. It brings theological students and ministers of all faiths (pastors, priests, rabbis, imams, and others) into supervised encounters with persons in crisis. At the conclusion of this course of study CPE students are considered competent in pastoral formation and providing spiritual support to people of diverse spiritual, religious, and cultural backgrounds. In North America, chaplains can receive certification from a number of the national organizations that are accredited by the COMISS Network Commission on Accreditation of Pastoral Services. ${ }^{62}$ They include the following:

- Association of Professional Chaplains (approximately 3700 members).

- The Canadian Association for Pastoral Practice and Education (approximately 1000 members).

- National Association of Catholic Chaplains (approximately 4000 members).

- National Association of Jewish Chaplains (approximately 400 members).

In addition to spiritual care training, there also needs to be palliative care training for all disciplines including chaplains. Palliative care education is increasing in the clinical disciplines but there is still an increased need for this education. Since 1990 these educational initiatives as well as research have given rise to the field of spirituality and health. While there have been significant advances, there is still a need for increased and more formalized training in spirituality and health in undergraduate health care professions curricula, as well as graduate, postgraduate, and continuing education. 
Chaplains have certification in spiritual care; it would be important to also have accountability measures for health care professionals involved in spiritual care based on their professional education.

\section{Recommendations}

1. All members of the palliative care team should be trained in spiritual care. This training should be required as part of continuing education for all clinicians. At a minimum, content of these educational programs should include:

a. All team members should have training in spiritual care commensurate with their scope of practice in regard to the spiritual care model. Health care professionals should be trained in doing a spiritual screening or history.

b. Health care professionals who care for patients are involved in diagnosis and treatment of clinical problems, and are involved in referring patients to specialists or resources should know the basics of spiritual diagnosis and treatment.

c. All team members should have knowledge of the options for addressing patients' spirituality, including spiritual resources and information.

d. Health care professionals should be trained in the tenets of different faiths and in different cultures in order to provide culturally and spiritually competent care.

e. As part of their training in cultural competency, all team members should have a broad minimum level of training in the spiritual/religious values and beliefs that may influence patient and family decisions regarding life-sustaining treatment and palliative care.

f. All team members should be aware of the training and differences in spiritual care providers and know when to refer to each.

g. All team members should have training in compassionate presence and active listening, and practice these competencies as part of the interprofessional team.

2. Team members should have training in self-care, selfreflection, contemplative practice, and spiritual selfcare.

3. Health care systems should offer time for professional development of staff with regard to spiritual care and develop accountability measures in spiritual care for the interprofessional team.

4. Board-certified chaplains can provide spiritual care education and support for the interprofessional team members.

5. Clinical sites should offer education for community clergy members and spiritual care providers about endof-life care, procedures in health care facilities, palliative care, patient confidentiality, self-care, and how to support health care professionals in their professional development. Education for seminary students regarding end-of-life care can be facilitated by collaborating with seminary accreditation organizations.

6. Development of chaplain certification and training in palliative care is needed.
7. Profession-specific (e.g., medicine, nursing, social work, psychology) competencies and training in spiritual care should be developed.

8. Spiritual education models should be interdisciplinary. Examples of educational programs that could be utilized include those from the Marie Curie Cancer Center $^{61}$ in London and the George Washington Institute for Spirituality and Health ${ }^{24}$ in Washington, D.C.

\section{Personal and Professional Development}

Spiritual care emphasizes the importance of relationships, ${ }^{63}$ therefore, health care is an inherently spiritual profession. Inherent to the proposed spiritual care model is the transformation that occurs when a health care professional and a patient interact in a professional relationship. Caring for people who suffer opens up the possibility of personal transformation for the health care professional. To be open to that, the professional must have an awareness of the spiritual dimensions of their own lives and then be supported in the practice of compassionate presence with patients through a reflective process.

When considering professional development and spiritual formation, health care providers must overcome barriers to the idea of health care as a spiritual undertaking. Health care providers form deeper and more meaningful connections with the patients by developing an awareness of their own values, beliefs, and attitudes, particularly regarding their own mortality. Many physicians and nurses speak of their own spiritual practices and how those practices help them deliver good spiritual care, which, in turn, helps in their ability to deliver good physical and psychosocial care to the seriously ill and dying patients. Reflective work is required in order to gain insight into one's own sense of spirituality, meaning, and professional calling in order to have the capacity to provide compassionate and skillful care. By being attentive to one's own spirituality and especially to one's sense of call to service to others, the health care professional may be able to find more meaning in his or her work and hence cope better with the stresses.

\section{Ethical considerations}

While advocating for the health care professional's attention to the spiritual needs of patients, it is recognized that certain special characteristics of the relationship between the health care professional and the patient help to shape how this is carried out in practice. The first important characteristic to note is the marked power imbalance between the professional and the patient. The sick, and especially those who are dying, often feel they have little control over their lives. All the power and control is perceived as belonging to the health care professional who must never exploit a patient's weakness or vulnerability. Health care professionals have a profound moral obligation to be trustworthy and to use their power in the interests of their patients. ${ }^{1,64}$

Second, there is a deep sense of intimacy regarding the spiritual aspects of a person's life. The one granted such access must exercise care, restraint, and confidentiality. Finally, it is important to recognize that while spiritual concerns can assume a particular importance at the end of life, attention to the spiritual needs of patients is not something to be reserved 
only for patients approaching death. Consistent with the philosophy of the NCP Guidelines and NQF Preferred Practices, palliative care is appropriate regardless of disease status, can begin at the time of early diagnosis, and attention to spiritual needs should be integrated across the trajectory of illness.

Boundaries. In order to ensure appropriate therapeutic relationships with patients and families, boundaries need to be recognized for the benefit of all concerned. Boundaries are mutually understood, unspoken physical, emotional, social, and spiritual limits for the health care professional and patient. The health care professional-patient relationship is often a one-way relationship that lacks equality and reciprocity. Boundaries allow for compassionate presence in the healing encounter. Health care professionals are more vulnerable to crossing these boundaries when they are overworked, stressed, or have experienced chronic losses or grief. Thus, it is critical that institutions and individual professionals make opportunities for appropriate self-care and reflection to avoid these risks.

Prohibition on Proselytizing in the Clinical Setting. Some clinicians may be motivated to proselytize by virtue of a zealous devotion to their own faith or spiritual commitments. A health care professional is never justified advising patients to "get religion" even if his or her intent is beneficent. Proselytizing within the clinical relationship is a violation of the trust the patient has give to the health care professional and inappropriate in the context of the professional relationship between the patient and the clinician.

Importantly, the prohibition on proselytizing should not be construed as a prohibition on asking patients about their spiritual or religious beliefs and practices. Skillful spiritual screening, history-taking, and assessments should not be threatening to patients or specific to one denomination, faith tradition, or philosophical orientation. Encounters regarding spirituality should not imply a particular answer that the patient can presume the health care professional considers "correct" but rather should open a dialogue that can be tailored to the specific needs of the individual patient.

\section{Recommendations}

1. Health care settings should support and encourage the health care professional's attention to self-care, reflection, retreat, and attention to stress management.

a. The role of spirituality in the health care professional's health, well-being, and resiliency to stress, as well as their ability to be compassionate, should be included in training and orientation for new staff members.

b. Reflective processes should be integrated into regular staff meetings and educational programs using rituals and care resources used for patients.

c. Environmental aesthetics should encourage reflection and foster self-nurturing behaviors.

2. Professional development should address spiritual development especially as it relates to the health care professional's sense of calling to their profession, the basis of relationshipcentered care, and provision of compassionate care.

a. Provide staff with the resources for basic spiritual care and for addressing spiritual and cultural issues of patients recognizing how the clinician's own spiritual and cultural background may influence how they provide care.

b. Integrate spirituality and self-care concepts into each profession's curriculum and continuing education programs.

c. Provide opportunities and resources for health care professionals in their life-long professional and spiritual growth within the clinical context, recognizing that intimate professional relationships can be transformational for health care professionals and patients.

3. The interprofessional team should be encouraged and given time for regular and ongoing self-examination (e.g., providing a safe, confidential space for compassionate listening at the work site, offering opportunities for off-site retreats, providing resources for referrals [spiritual directors, therapists] as needed).

4. Health care settings should provide opportunities to develop and sustain healthy teams and a sense of connectedness and community. Opportunities may include: a. Structured interprofessional teams that honor the voice of all members and value a sense of mutual support.

b. Ritual and reflections in team meetings.

c. Provision of onsite staff support for team-building.

5. Institutions should provide opportunities for the interprofessional team to discuss ethical issues as they arise.

a. Health care professionals must be reminded and cautioned regarding the power imbalances that characterize the health care environment. Spirituality should be defined broadly to be inclusive of religious, philosophical, and existential or personal beliefs, values, and practices and centered on patient preferences.

b. Discussions should include a virtues-based ethics approach to address complex spiritual concerns. ${ }^{65}$

c. Health care professionals should be afforded the opportunity to discuss spiritual and ethical conflicts and issues they encounter in working with patients and other health care professionals.

\section{Quality Improvement}

The process of quality improvement is widely recognized in all health care settings. There is an increased emphasis on improving the quality or performance of health care services through application of standard approaches adapted from business and industry. Well-established quality improvement efforts in health care have addressed common and costly patient care concerns such as safety, infection control, relief of common symptoms, patient adherence, and other aspects of patient care delivery. While quality improvement approaches vary, common features include assessment of the current status of care, planning of strategies for improved care, implementation of these strategies, and ongoing evaluation of outcomes with continued refinement of care. ${ }^{66}$

As hospice and palliative care have emerged as major aspects of health care delivery, these settings have adapted quality improvement methods from acute care settings. Hospices have been increasingly pressured to demonstrate effectiveness and pioneering, hospital-based palliative care programs have also applied quality improvement strategies to design, implement, and evaluate their services. Common aspects of hospice and palliative care targeted for improvement 
have included relief of pain and symptoms, delivery of bereavement services, patient and family satisfaction with care, use of advanced directives, avoidance of life-prolonging therapies, the ability of these programs to achieve patient goals of care, and attention to desires about place for death. ${ }^{67,68}$

\section{Application of quality improvement to spiritual care}

The domain of spiritual care has received less attention than other aspects of palliative care within quality improvement efforts ${ }^{69}$ in part because there are many challenges to application of quality improvement efforts in spiritual care. The well-defined guidelines for spiritual care that have been advanced by $\mathrm{NCP}, \mathrm{NQF}$, and this Consensus Report can provide an established standard of quality that can be targeted for improvement. Nevertheless, it is important to acknowledge that the existential quality of spiritual care makes quantification of outcomes a challenge. Assessing relief of suffering, forgiveness, meaning in life, and other abstract aspects of spiritual care require approaches that exceed the capacity of the usual quantitative metrics applied to other aspects of health care. Therefore, spiritual experts need to have creative input into developing measures that will adequately assess spiritual care. Spiritual metrics that reflect the goals of spiritual care need to be developed. These metrics might include an increase in chaplain referrals, improved patient satisfaction, and lower scores on a spiritual distress scale as a result of attention to patients' spiritual concerns.

Improving the quality of spiritual care as a function of quality improvement processes will require attention to the unique aspects of this domain of care. Some quantitative approaches may be applicable. For example, hospice and palliative care programs can adapt quantitative methods for assessing referrals to chaplaincy, rates of completion of spiritual assessment, and the incorporation of desired rituals into the treatment plan. However, qualitative approaches also will be needed to capture the unique aspects of spiritual care. Data derived from patient or family interviews, staff focus groups, and reflections on patient care can inform palliative care programs in their quest to improve the quality of spiritual care.

\section{Quality improvement frameworks}

The NCP Guidelines, ${ }^{21}$ NQF Preferred Practices, ${ }^{22}$ and recommendations from this Consensus Report provide a shared framework for palliative care programs. There is tremendous opportunity for the palliative care community to advance the critical aspect of spiritual care. Application of these recommendations followed by meaningful evaluation can improve the quality of spiritual care delivered to patients and families. Attention to spiritual care by accrediting bodies, such as The Joint Commission, can further advance spiritual care in the knowledge that without quality spiritual care, quality palliative care will not be achieved.

\section{Recommendations}

1. All palliative care programs should include the domain of spiritual care within their overall quality improvement plans. Spirituality should be a component of electronic medical records. Clinical settings should monitor the quality of care specifically with regards to spiritual care at the time of death. Measurable outcomes can include pa- tient and staff satisfaction and quality of life. Process measures can include rates of chaplain referral and timelines of completion of routine spiritual assessment among other metrics.

2. Assessment tools should be evaluated to determine which are most efficacious and clinically relevant. Tools and measurement techniques across palliative care settings should be standardized.

3. Quality improvement frameworks based on NCP Guidelines that relate to structure, process, and outcomes of spiritual care need to be developed.

4. Building on tested quality improvement models (e.g., pain management), quality improvement efforts specific to spiritual care should be tested and applied.

5. Research that will contribute to improving spiritual care outcomes to palliative care patients should be supported. Recognizing the complex definition of spirituality and its difficulty in measurement, studies should use multiple quantitative and qualitative methods for evaluation.

6. Funding to evaluate the current state of the science, establish a research agenda, and facilitate research opportunities for spiritual care research should be sought.

\section{Conclusion}

Spiritual care is an essential domain of quality palliative care as determined by NCP and NQF. Studies have indicated the strong desire of patients with serious illness and end-oflife concerns to have spirituality included in their care. There is a strong empirical and scholarly body of literature to support the inclusion of spiritual care as part of a biopsychosocial-spiritual approach to care. Based on the position that palliative care encompasses the care of all patients from the time of diagnosis of spiritual illness, the principles in this Consensus Report can be applied to the care of most patients. In this report, practical recommendations are provided for the implementation of spiritual care in palliative, hospice, hospital, long-term, and other clinical settings. Critical to the implementation of these recommendations will be interprofessional care that includes board-certified chaplains on the care team, regular ongoing assessment of patients' spiritual issues, integration of patient spirituality into the treatment plan with appropriate follow-up with ongoing quality improvement, professional education and development of programs, and adoption of these recommendations into clinical site policies.

By utilizing the recommendations set forth in this document, clinical sites can integrate spiritual care models into their programs, develop interprofessional training programs, engage community clergy and spiritual leaders in the care of patients and families, promote professional development that incorporates a biopsychosocial-spiritual practice model, and develop accountability measures to ensure that spiritual care is fully integrated into the care of patients.

Tools and resources for implementation of spiritual care can be submitted to SOERCE, an online resource center on gwish.org

\section{Acknowledgments}

The Project Team is deeply grateful to the Archstone Foundation, Long Beach, CA, as part of their End-of-Life 
Initiative, for the financial support that made this project possible.

A consensus process brings together the thoughts and contributions of many individuals. Thank you to all the health care professionals who gave their support, experience, and comments to this Consensus Report. The authors also acknowledge the editorial assistance of Rose Mary CarrollJohnson, M.N., R.N.

\section{Author Disclosure Statement}

No competing financial interests exist.

\section{References}

1. Astrow AB, Puchalski CM, Sulmasy DP: Religion, spirituality, and health care: Social, ethical, and practical considerations. Am J Med 2001;110:283-287.

2. Frankl VE: Man's Search for Meaning. New York: Washington Square Press, 1963.

3. King DE, Bushwick B: Beliefs and attitudes of hospital inpatients about faith healing and prayer. J Fam Pract 1994; 39:349-352.

4. Puchalski CM, Dorff RE, Hendi IY: Spirituality, religion, and healing in palliative care. Clin Geriatr Med 2004;20:689-714.

5. Sulmasy DP: Is medicine a spiritual practice? Acad Med 1999;74:1002-1005.

6. Kalb C: Faith \& healing. Newsweek November 10, 2003:44.

7. Kluger J: The biology of belief. Time February 23, 2009;173: 62-64, 66, 70 .

8. Sheler JL: Drugs, scalpel . . and faith? US News World Rep Jul 2, 2001;131:46-47.

9. Balboni TA, Vanderwerker LC, Block SD, Paulk ME, Lathan CS, Peteet JR, Prigerson HG: Religiousness and spiritual support among advanced cancer patients and associations with end-of-life treatment preferences and quality of life. J Clin Oncol 2007;25:555-560.

10. McCord G, Gilchrist, VJ, Grossman, SD, King, BD, McCormick, KE, Oprandi AM, Schrop SL, Selius BA, Smucker DO, Weldy DL, Amorn M, Carter MA, Deak AJ, Hefzy H, Srivastava M: Discussing spirituality with patients: A rational and ethical approach. Ann Fam Med 2004;2:356-361.

11. Phelps AC, Maciejewski PK, Nilsson M, Balboni TA, Wright AA, Paulk ME, Trice E, Schrag D, Peteet JR, Block SD, Prigerson HG: Religious coping and use of intensive lifeprolonging care near death in patients with advanced cancer. JAMA 2009;301:1140-1147.

12. Silvestri GA, Knittig S, Zoller JS, Nietert PJ: Importance of faith on medical decisions regarding cancer care. I Clin Oncol 2003;2:1379-1382.

13. Burgener SC: Predicting quality of life in caregivers of Alzheimer's patients: The role of support from and involvement with the religious community. J Pastoral Care Counsel 1999; 53:433-446.

14. Cohen SR, Mount, BM, Strobel MG, Bui F: The McGill quality of life questionnaire: A measure of quality of life appropriate for people with advanced disease. A preliminary study of validity and acceptability. Palliat Med 1995;9:207-219.

15. Cohen SR, Mount BM, Tomas JJ, Mount LF: Existential wellbeing is an important determinant of quality of life. Evidence from the McGill quality of life questionnaire. Cancer 1996;77:576-586.

16. Koenig HG, McCullough ME, Larson DB: Handbook of Religion and Health. New York: Oxford University Press, 2001.
17. Roberts JA, Brown D, Elkins T, Larson DB: Factors influencing views of patients with gynecologic cancer about endof-life decisions. Am J Obstet Gynecol 1997;176:166-172.

18. Tsevat J, Sherman SN, McElwee JA, Mandell K, Simbartl LA, Sonnenberg FA, Fowler FJ: The will to live among HIVinfected patients. Ann Intern Med 1999;131:194-198.

19. Fitchett G, Murphy PE, Kim J, Gibbons JL, Cameron JR, Davis JA: Religious struggle: Prevalence, correlates and mental health risks in diabetic, congestive heart failure, and oncology patients. Int J Psychiatry Med 2004;34:179-196.

20. Pargament KI, Koenig HG, Tarakeshwar N, Hahn J: Religious coping methods as predictors of psychological, physical and spiritual outcomes among medically ill elderly patients: A two-year longitudinal study. J Health Psychol 2004;9:713-730.

21. National Consensus Project: Quality Palliative Care Guidelines. www.nationalconsensusproject.org (Last accessed April 2, 2009).

22. National Quality Forum: A National Framework and Preferred Practices for Palliative and Hospice Care: A Consensus Report. www.qualityforum.org/publications/reports/ palliative.asp (Last accessed April 2, 2009).

23. National Consensus Project for Quality Palliative Care: Clinical practice guidelines for quality palliative care: Executive summary. I Palliat Med 2004;7:611-627.

24. George Washington Institute for Spirituality and Health. www.gwish.org (Last accessed April 2, 2009).

25. Association of American Medical Colleges: Report III. Contemporary issues in medicine. Medical school objectives project (MSOP III). https://services.aamc.org/Publications/ showfile.cfm?file $=$ version89.pdf\&prd_id $=200 \& p r v \_i d=241$ \&pdf_id=89 (Last accessed April 2, 2009).

26. Nelson-Becker H: Integrating spirituality in practice: From inner journey to outer engagement. J Geriatr Care Manage 2008;10:10-15.

27. O'Connor P: The role of spiritual care in hospice. Are we meeting patients' needs? Am J Hosp Care 1988;5:31-37.

28. Barnum BS: Spirituality in Nursing: From Traditional to New Age. New York: Springer, 1996.

29. Sulmasy DP: A biopsychosocial-spiritual model for the care of patients at the end of life. Gerontologist 2002;42(Spec No 3):24-33.

30. Institute for Alternative Futures: Patient-centered Care 2015: Scenarios, Vision, Goals \& Next Steps. www.altfutures.com/ pubs/Picker\%20Final\%20Report\%20May\%2014\%202004.pdf (Last accessed April 2, 2009).

31. Engel GL: The need for a new medical model: A challenge for biomedicine. Science 1977;196:129-136.

32. White KL, Williams TF, Greenberg BG: The ecology of medical care. Bull NY Acad Med 1996;73:187-205.

33. Jonas H: The Phenomenon of Life: Towards a Philosophical Biology. Evanston, IL: Northwestern University Press, 2001.

34. Sulmasy DP: The Rebirth of the Clinic: An Introduction to Spirituality in Health Care. Washington, D.C: Georgetown University Press, 2006.

35. Ramsey P: The Patient as Person. New Haven, CT: Yale University Press, 1970.

36. Engel GL: How much longer must medicine's science be bound by a seventeenth century world view? Psychotherapy Psychosomatics 1992;57:3-16.

37. King DE: Faith, Spirituality and Medicine: Toward the Making of a Healing Practitioner. Binghamton, NY: Haworth Pastoral Press, 2000.

38. McKee DD, Chappel JN: Spirituality and medical practice. J Fam Pract 1992;5:201, 205-208. 
39. Anandarajah G, Hight E: Spirituality and medical practice: Using the HOPE questions as a practical tool for spiritual assessment. Am Fam Physician 2001;63:81-89.

40. Maugans TA: The SPIRITual history. Fam Med 1996;5:11-16.

41. Puchalski CM: Spiritual assessment in clinical practice. Psychiatr Ann 2006;36:150.

42. Lo B, Ruston D, Kates LW, Arnold RM, Cohen CB, FaberLangendoen K, Pantilat SZ, Puchalski CM, Quill TR, Rabow MW, Schreiber S, Sulmasy DP, Tulsky JA: Discussing religious and spiritual issues at the end of life: A practical guide for physicians. IAMA 2002;287:749-754.

43. Puchalski C, Romer AL: Taking a spiritual history allows clinicians to understand patients more fully. J Palliat Med 2000;3:129-137.

44. Nelson-Becker H, Nakashima M, Canda ER: Oxford Handbook of Social Work in Health and Aging. New York: Oxford University Press, 2006.

45. Monroe MH, Bynum D, Susi B, Phifer N, Schultz L, Franco M, MacLean CD, Cykert S, Garrett J: Primary care physician preferences regarding spiritual behavior in medical practice. Arch Intern Med 2003;163:2751-2756.

46. Taylor EJ: Prayer's clinical issues and implications. J Holist Nurs 2003;17:179-188.

47. Stanford Medical Center, ABC News, USA Today: Broad Experience with Pain Sparks a Search for Relief. http:// abcnews.go.com/images/Politics/979a1TheFightAgainstPain .pdf (Last accessed May 27, 2009).

48. Lo B, Kates LW, Ruston D, Arnold RM, Cohen CB, Puchalski CM, Pantilat SZ, Rabow MW, Schreiber RS, Tulsky JA: Responding to requests regarding prayer and religious ceremonies by patients near the end of life and their families. J Palliat Med 2003;6:409-415.

49. Fitchett G: Assessing Spiritual Needs: A Guide for Caregivers. Lima, OH: Academic Renewal Press, 2002.

50. National Comprehensive Cancer Network: Distress Management Guidelines. www.nccn.org/professionals/physician_gls/ f_guidelines.asp (Last accessed April 2, 2009).

51. American Psychological Association: Diagnostic and Statistical Manual, version IV. Chicago, IL: American Psychological Association, 2004.

52. NANDA International: Nursing Diagnosis: Definitions and Classifications 2009-2011. West Sussuex, UK: Wiley-Blackwell, 2009.

53. Abrahmson JS, Mizrahi T: Understanding collaboration between social workers and physicians: Application of a typology. Soc Work Health Care 2003;37:71-100.

54. Dunevitz B: Collaboration-in a variety of ways-creates health care value. Nurs Econ 1997;15:218-219.

55. Netting FE, Williams FG: Case manager-physician collaboration: Implications for professional identity, roles, and relationships. Health Soc Work 1996;21:216-224.

56. Payne M: Teamwork in Multiprofessional Care. Chicago, IL: Lyceum Books, 2000.
57. Joint Commission: Spiritual Assessment. www .jointcommission.org/AccreditationPrograms/HomeCare/ Standards/09_FAQs/PC/Spiritual_Assessment.htm (Last accessed April 2, 2009).

58. American Association of Colleges of Nursing: The Essentials Of Baccalaureate Education For Professional Nursing Practice. Washington, D.C.: American Association of Colleges of Nursing, 2008.

59. Lemmer $C$ : Teaching the spiritual dimension of nursing care: A survey of U.S. baccalaureate nursing programs. J Nurs Educ 2002;41:482-490.

60. National Association of Social Workers. Code of Ethics. www.socialworkers.org/pubs/code/code.asp (Last accessed December 10, 2008).

61. Marie Curie Cancer Care: Spiritual \& Religious Care Competencies for Specialist Palliative Care. www.mariecurie .org.uk/forhealthcareprofessionals/spiritualandreligiouscarndreligiouscare/index.htm (Last accessed April 2, 2009).

62. COMISS Commission for Accreditation of Pastoral Services: www.comissnetwork.org/ (Last accessed May 28, 2009).

63. Puchalski CM: Honoring the sacred in medicine: Spirituality as an essential element of patient-centered care. J Med Person 2008;6:113-117.

64. Post SG, Puchalski CM, Larson DB: Physicians and patient spirituality: Professional boundaries, competency, and ethics. Ann Intern Med 2000;132:578-583.

65. Pellegrino ED, Thomasma, DC: Virtue-based ethics: natural and theological. In: Pellegrino ED,Thomasma DC (eds): The Christian Virtues in Medical Practice. Washington, D.C.: Georgetown University Press, 1996, pp. 6-28.

66. Kelly D: Applying Quality Management in Healthcare: A Systems Approach, $2^{\text {nd }}$ ed. Chicago, IL: Health Administration Press, 2007.

67. Brunnhuber K, Nash S, Meier DE, Weissman DE, Woodcock J: Putting Evidence into Practice: Palliative Care. London: BMJ Publishing Group, 2008.

68. Twaddle ML, Maxwell TL, Cassel, JB, Liao S, Coyne PJ, Usher B M, Amin A, Cuny J: Palliative care benchmarks from academic medical centers. I Palliat Med 2007;10:8698.

69. Kapp SA, Nelson-Becker HB: Evaluating hospice services for improvement: A manageable approach. I Pain Palliat Care Pharmacother 2007;21:17-26.

Address correspondence to: Betty Ferrell, Ph.D., M.A., F.A.A.N., F.P.C.N. Department of Nursing Research and Education City of Hope National Medical Center 1500 East Duarte Road Duarte, CA 91010

E-mail: bferrell@coh.org 


\section{This article has been cited by:}

1. Christina M. Puchalski, Raya Kheirbek, Ann Doucette, Toby Martin, Y. Tony Yang. 2013. Spirituality as an essential element of person-centered compassionate care: a pilot training program for clinicians. Journal of Medicine and the Person 11:2, 56-61. [CrossRef]

2. Katherine R. Sterba, Jane Zapka, Elena I. Gore, Marvella E. Ford, Dee W. Ford, Melanie Thomas, Kristin Wallace. 2013. Exploring Dimensions of Coping in Advanced Colorectal Cancer: Implications for Patient-Centered Care. Journal of Psychosocial Oncology 130711115000005. [CrossRef]

3. José Carlos Bermejo Higuera, Bernardino Lozano González, Marta Villacieros Durbán, Milagros Gil Vela. 2013. Atención espiritual en cuidados paliativos. Valoración y vivencia de los usuarios. Medicina Paliativa 20:3, 93-102. [CrossRef]

4. John R. Peteet, Michael J. Balboni. 2013. Spirituality and religion in oncology. CA: A Cancer Journal for Clinicians 63:4, 280-289. [CrossRef]

5. Betty Ferrell, Shirley Otis-Green, Reverend Pamela Baird, Andrea Garcia. 2013. Nurses' Responses to Requests for Forgiveness at the End of Life. Journal of Pain and Symptom Management . [CrossRef]

6. H. Nelson-Becker, A. L. Ai, F. P. Hopp, T. R. McCormick, J. O. Schlueter, J. K. Camp. 2013. Spirituality and Religion in Endof-Life Care Ethics: The Challenge of Interfaith and Cross-Generational Matters. British Journal of Social Work . [CrossRef]

7. Lois M. Ramondetta, Charlotte Sun, Antonella Surbone, Ian Olver, Carla Ripamonti, Tatsuya Konishi, Lea Baider, Judith Johnson. 2013. Surprising results regarding MASCC members' beliefs about spiritual care. Supportive Care in Cancer . [CrossRef]

8. C. Gamondi, M. Pott, S. Payne. 2013. Families' experiences with patients who died after assisted suicide: a retrospective interview study in southern Switzerland. Annals of Oncology 24:6, 1639-1644. [CrossRef]

9. Joanna Bulkley, Carmit K. McMullen, Mark C. Hornbrook, Marcia Grant, Andrea Altschuler, Christopher S. Wendel, Robert S. Krouse. 2013. Spiritual well-being in long-term colorectal cancer survivors with ostomies. Psycho-Oncology n/a-n/a. [CrossRef]

10. Ingela Henoch, Ella Danielson, Susann Strang, Maria Browall, Christina Melin-Johansson. 2013. Training Intervention for Health Care Staff in the Provision of Existential Support to Patients With Cancer: A Randomized, Controlled Study. Journal of Pain and Symptom Management . [CrossRef]

11. Giancarlo Lucchetti, Rodrigo M. Bassi, Alessandra L. Granero Lucchetti. 2013. Taking Spiritual History in Clinical Practice: A Systematic Review of Instruments. EXPLORE: The Journal of Science and Healing 9:3, 159-170. [CrossRef]

12. Marie-José H.E. Gijsberts, Jenny T. van der Steen, Martien T. Muller, Cees M.P.M. Hertogh, Luc Deliens. 2013. Spiritual Endof-Life Care in Dutch Nursing Homes: An Ethnographic Study. Journal of the American Medical Directors Association . [CrossRef]

13. Julie J. Exline, Maryjo Prince-Paul, Briana L. Root, Karen S. Peereboom. 2013. The Spiritual Struggle of Anger toward God: A Study with Family Members of Hospice Patients. Journal of Palliative Medicine 16:4, 369-375. [Abstract] [Full Text HTML] [Full Text PDF] [Full Text PDF with Links]

14. Erin Lane Cook, Michael J. Silverman. 2013. Effects of music therapy on spirituality with patients on a medical oncology/ hematology unit: A mixed-methods approach. The Arts in Psychotherapy 40:2, 239-244. [CrossRef]

15. Laura Galiana, Amparo Oliver, Clara Gomis, Javier Barbero, Enric Benito. 2013. Cuestionarios de evaluación e intervención espiritual en cuidados paliativos: una revisión crítica. Medicina Paliativa . [CrossRef]

16. Denise Hess. 2013. Faith Healing and the Palliative Care Team. Journal of Social Work in End-Of-Life \& Palliative Care 9:2-3, 180-190. [CrossRef]

17. Holly Nelson-Becker. 2013. Spirituality in End-of-Life and Palliative Care: What Matters?. Journal of Social Work in End-OfLife \& Palliative Care 9:2-3, 112-116. [CrossRef]

18. Donald E. Healy. 2013. And What Did I Do?. Journal of Social Work in End-Of-Life \& Palliative Care 9:2-3, 117-122. [CrossRef]

19. Simon Dein, John Swinton, Syed Qamar Abbas. 2013. Theodicy and End-of-Life Care. Journal of Social Work in End-Of-Life \& Palliative Care 9:2-3, 191-208. [CrossRef]

20. Arndt Büssing. 2013. Psychosocial and spiritual needs of patients with chronic diseases: validation of the Chinese version of the Spiritual Needs Questionnaire. Journal of Integrative Medicine 11:2, 106-115. [CrossRef]

21. Shirley Otis-Green, Mark T. Wakabayashi, Robert Morgan, Amy Hakim, Betty Ferrell, Virginia Sun, Eunice Yang, Marcia Grant. 2013. Palliative Care Opportunities for Women with Advanced Ovarian Cancer Associated with Intraperitoneal Chemotherapy. Journal of Palliative Medicine 16:1, 44-53. [Abstract] [Full Text HTML] [Full Text PDF] [Full Text PDF with Links]

22. Pippa Hall, Lynda Weaver, Pamela Anne Grassau. 2013. Theories, relationships and interprofessionalism: Learning to weave. Journal of Interprofessional Care 27:1, 73-80. [CrossRef] 
23. Ursula McVeigh, Allan RamsayPalliative Care 582-587. [CrossRef]

24. Robyn M. Keall, Phyllis N. Butow, Karen E. Steinhauser, Josephine M. Clayton. 2013. Nurse-Facilitated Preparation and Life Completion Interventions Are Acceptable and Feasible in the Australian Palliative Care Setting. Cancer Nursing 36:3, E39-E46. [CrossRef]

25. Paul Galchutt. 2013. A Palliative Care Specific Spiritual Assessment: How This Story Evolved. OMEGA--Journal of Death and Dying 67:1, 79-85. [CrossRef]

26. Linda F. Piotrowski. 2013. Advocating and Educating for Spiritual Screening Assessment and Referrals to Chaplains. OMEGA-Journal of Death and Dying 67:1, 185-192. [CrossRef]

27. Donnelle Daly, Stephen Chavez Matzel. 2013. Building a Transdisciplinary Approach to Palliative Care in an Acute Care Setting. OMEGA--Journal of Death and Dying 67:1, 43-51. [CrossRef]

28. Hillel Bodek. 2013. Facilitating the Provision of Quality Spiritual Care in Palliative Care. OMEGA--Journal of Death and Dying 67:1, 37-41. [CrossRef]

29. Renske Kruizinga, Michael Scherer-Rath, Johannes BAM Schilderman, Mirjam AG Sprangers, Hanneke WM Van Laarhoven. 2013. The life in sight application study (LISA): design of a randomized controlled trial to assess the role of an assisted structured reflection on life events and ultimate life goals to improve quality of life of cancer patients. BMC Cancer 13:1, 360. [CrossRef]

30. Bei-Hung Chang, Nathan R. Stein, Kelly Trevino, Max Stewart, Ann Hendricks, Lara M. Skarf. 2012. End-of-life spiritual care at a VA medical center: Chaplains' perspectives. Palliative and Supportive Care 10:04, 273-278. [CrossRef]

31. Judith H. Blanchard, Douglas A. Dunlap, George Fitchett. 2012. Screening for spiritual distress in the oncology inpatient: a quality improvement pilot project between nurses and chaplains. Journal of Nursing Management n/a-n/a. [CrossRef]

32. Maureen E. Lyon, Patricia Garvie, Jianping He, Robert Malow, Robert McCarter, Lawrence J. D’Angelo. 2012. Spiritual WellBeing Among HIV-Infected Adolescents and Their Families. Journal of Religion and Health . [CrossRef]

33. Mieke Vermandere, Jan De Lepeleire, Wouter Van Mechelen, Franca Warmenhoven, Bregje Thoonsen, Bert Aertgeerts. 2012. Spirituality in palliative home care: a framework for the clinician. Supportive Care in Cancer . [CrossRef]

34. Carol Taylor. 2012. Rethinking Hopelessness and the Role of Spiritual Care When Cure Is No Longer an Option. Journal of Pain and Symptom Management 44:4, 626-630. [CrossRef]

35. Thomas R. McCormick, Faith Hopp, Holly Nelson-Becker, Amy L. Ai, Judith O. Schlueter, Jessica K. Camp. 2012. Ethical and Spiritual Concerns Near the End of Life. Journal of Religion, Spirituality \& Aging 24:4, 301-313. [CrossRef]

36. Barbara A. Elliott, Charles E. Gessert, Pamela Larson, Thomas E. Russ. 2012. Religious Beliefs and Practices in End-Stage Renal Disease: Implications for Clinicians. Journal of Pain and Symptom Management 44:3, 400-409. [CrossRef]

37. John Eric Baugher, Molly McIntyre, Candice House, Mary Mawhinney, Brittany O'Brien, Andrew J. Reagan. 2012. When grieving adults support grieving children: tensions in a peer support bereavement group programme. Mortality 17:3, 276-299. [CrossRef]

38. Alicia Krikorian, Joaquín T. Limonero, Jorge Maté. 2012. Suffering and distress at the end-of-life. Psycho-Oncology 21:8, 799-808. [CrossRef]

39. Judy A. Schreiber. 2012. Psychometric Properties of the Image of God Scale in Breast Cancer Survivors. Oncology Nursing Forum 39:4, E346-E352. [CrossRef]

40. Claire J. Creutzfeldt, Robert G. Holloway, Melanie Walker. 2012. Symptomatic and Palliative Care for Stroke Survivors. Journal of General Internal Medicine 27:7, 853-860. [CrossRef]

41. David W. Kissane, Carrie E. Lethborg, Brian KellySpiritual and Religious Coping with Cancer 281-295. [CrossRef]

42. Mark Cobb, Christopher Dowrick, Mari Lloyd-Williams. 2012. What Can We Learn About the Spiritual Needs of Palliative Care Patients From the Research Literature?. Journal of Pain and Symptom Management 43:6, 1105-1119. [CrossRef]

43. Consuelo Tosao Sánchez. 2012. Abordaje aconfesional de la espiritualidad en cuidados paliativos. FMC - Formación Médica Continuada en Atención Primaria 19:6, 331-338. [CrossRef]

44. Kristopher Dennis, Graeme Duncan. 2012. Spiritual care in a multicultural oncology environment. Current Opinion in Supportive and Palliative Care 6:2, 247-253. [CrossRef]

45. Benjamin W. Corn, Harvey M. Chochinov, Mary Vachon. 2012. Integrating spiritual care into the practice of oncology. Current Opinion in Supportive and Palliative Care 6:2, 226-227. [CrossRef]

46. Nora M. El Nawawi, Michael J. Balboni, Tracy A. Balboni. 2012. Palliative care and spiritual care. Current Opinion in Supportive and Palliative Care 6:2, 269-274. [CrossRef]

47. Christina M. Puchalski, Margaret Guenther. 2012. Restoration and re-creation. Current Opinion in Supportive and Palliative Care 6:2, 254-258. [CrossRef] 
48. Shane Sinclair, Harvey M. Chochinov. 2012. The role of chaplains within oncology interdisciplinary teams. Current Opinion in Supportive and Palliative Care 6:2, 259-268. [CrossRef]

49. Naomi Kalish. 2012. Evidence-based spiritual care. Current Opinion in Supportive and Palliative Care 6:2, 242-246. [CrossRef]

50. Henry S. Perkins, Josie D. Cortez, Helen P. Hazuda. 2012. Diversity of Patients' Beliefs about the Soul after Death and Their Importance in End-of-Life Care. Southern Medical Journal 105:5, 266-272. [CrossRef]

51. Dee W. Ford. 2012. Religion and end-of-life decisions in critical care: where the word meets deed. Intensive Care Medicine . [CrossRef]

52. C. M. Puchalski. 2012. Spirituality in the cancer trajectory. Annals of Oncology 23:suppl 3, 49-55. [CrossRef]

53. Jina Kang, Dong Wook Shin, Jin Young Choi, Chang Hae Park, Young Ji Baek, Ha Na Mo, Mi Ok Song, Shin Ae Park, Do Ho Moon, Ki Young Son. 2012. Addressing the religious and spiritual needs of dying patients by healthcare staff in Korea: patient perspectives in a multi-religious Asian country. Psycho-Oncology 21:4, 374-381. [CrossRef]

54. Shirley Otis-Green, Betty Ferrell, Tami Borneman, Christina Puchalski, Gwen Uman, Andrea Garcia. 2012. Integrating Spiritual Care within Palliative Care: An Overview of Nine Demonstration Projects. Journal of Palliative Medicine 15:2, 154-162. [Citation] [Full Text HTML] [Full Text PDF] [Full Text PDF with Links]

55. Dee W. Ford, Lois Downey, Ruth Engelberg, Anthony L. Back, J. Randall Curtis. 2012. Discussing Religion and Spirituality Is an Advanced Communication Skill: An Exploratory Structural Equation Model of Physician Trainee Self-Ratings. Journal of Palliative Medicine 15:1, 63-70. [Abstract] [Full Text HTML] [Full Text PDF] [Full Text PDF with Links]

56. Arjan W. Braam, Marianne Klinkenberg, Henrike Galenkamp, Dorly J. H. Deeg. 2012. Late-Life Depressive Symptoms, Religiousness, and Mood in the Last Week of Life. Depression Research and Treatment 2012, 1-10. [CrossRef]

57. Michael Schultz, Kassim Baddarni, Gil Bar-Sela. 2012. Reflections on Palliative Care from the Jewish and Islamic Tradition. Evidence-Based Complementary and Alternative Medicine 2012, 1-8. [CrossRef]

58. Stefanie Monod, Estelle Martin, Brenda Spencer, Etienne Rochat, Christophe Büla. 2012. Validation of the spiritual distress assessment tool in older hospitalized patients. BMC Geriatrics 12:1, 13. [CrossRef]

59. Giancarlo Lucchetti, Alessandra Lamas Lucchetti, Daniele Corcioli Espinha, Leandro de Oliveira, José Leite, Harold G Koenig. 2012. Spirituality and health in the curricula of medical schools in Brazil. BMC Medical Education 12:1, 78. [CrossRef]

60. Mozhgan Rahnama, Masoud Khoshknab, Sadat Seyed Maddah, Fazlollah Ahmadi. 2012. Iranian cancer patients' perception of spirituality: a qualitative content analysis study. BMC Nursing 11:1, 19. [CrossRef]

61. Kathryn A. Lyndes, George Fitchett, Nancy Berlinger, Wendy Cadge, Jennifer Misasi, Erin Flanagan. 2012. A Survey of Chaplains' Roles in Pediatric Palliative Care: Integral Members of the Team. Journal of Health Care Chaplaincy 18:1-2, 74-93. [CrossRef]

62. Ann Harrington. 2012. A Beginning Understanding of Caregivers' Spiritual Needs When Relinquishing a Loved One to a Palliative Care Setting. Journal of Religion, Spirituality \& Aging 24:1-2, 131-145. [CrossRef]

63. John R. Peteet. 2012. Spiritually Integrated Treatment of Depression: A Conceptual Framework. Depression Research and Treatment 2012, 1-6. [CrossRef]

64. John W. Fisher, David Brumley. 2012. Palliative Care Doctors Need Help with Spiritual Wellbeing. Journal for the Study of Spirituality 2:1, 49-60. [CrossRef]

65. Judith A. Schreiber, Dorothy Y. Brockopp. 2011. Twenty-five years later-what do we know about religion/spirituality and psychological well-being among breast cancer survivors? A systematic review. Journal of Cancer Survivorship . [CrossRef]

66. Giancarlo Lucchetti, Alessandra Lamas Granero Lucchetti, Christina M. Puchalski. 2011. Spirituality in Medical Education: Global Reality?. Journal of Religion and Health . [CrossRef]

67. George Handzo. 2011. Spiritual Care for Palliative Patients. Current Problems in Cancer 35:6, 365-371. [CrossRef]

68. Elizabeth M. Tait, Sarah B. Laditka, James N. Laditka, Mary A. Nies, Elizabeth F. Racine. 2011. Praying for Health by Older Adults in the United States: Differences by Ethnicity, Gender, and Income. Journal of Religion, Spirituality \& Aging 23:4, 338-362. [CrossRef]

69. Carol O. Long. 2011. Cultural and Spiritual Considerations in Palliative Care. Journal of Pediatric Hematology/Oncology 33, S96S101. [CrossRef]

70. Richard Egan, Rod MacLeod, Chrystal Jaye, Rob McGee, Joanne Baxter, Peter Herbison. 2011. What is spirituality? Evidence from a New Zealand hospice study. Mortality 1-18. [CrossRef]

71. William D. Winkelman, Katharine Lauderdale, Michael J. Balboni, Andrea C. Phelps, John R. Peteet, Susan D. Block, Lisa A. Kachnic, Tyler J. VanderWeele, Tracy A. Balboni. 2011. The Relationship of Spiritual Concerns to the Quality of Life of 
Advanced Cancer Patients: Preliminary Findings. Journal of Palliative Medicine 14:9, 1022-1028. [Abstract] [Full Text HTML] [Full Text PDF] [Full Text PDF with Links]

72. Xavier Gómez-Batiste, Montse Buisan, M. Pau González, David Velasco, Verónica de Pascual, Jose Espinosa, Anna Novellas, Marisa Martínez-Muñoz, Marc Simón, Candela Calle, Jaume Lanaspa, William Breitbart. 2011. The "La Caixa" Foundation and WHO Collaborating Center Spanish National Program for enhancing psychosocial and spiritual palliative care for patients with advanced diseases, and their families: Preliminary findings. Palliative and Supportive Care 9:03, 239-249. [CrossRef]

73. Urška Lunder, Maja Furlan, Anja Simonič. 2011. Spiritual needs assessments and measurements. Current Opinion in Supportive and Palliative Care 5:3, 273-278. [CrossRef]

74. Arif H. Kamal, David C. Currow, Christine Ritchie, Janet Bull, Jane L. Wheeler, Amy P. Abernethy. 2011. The Value of Data Collection within a Palliative Care Program. Current Oncology Reports 13:4, 308-315. [CrossRef]

75. Stéfanie Monod, Mark Brennan, Etienne Rochat, Estelle Martin, Stéphane Rochat, Christophe J. Büla. 2011. Instruments Measuring Spirituality in Clinical Research: A Systematic Review. Journal of General Internal Medicine . [CrossRef]

76. Marie-José H.E. Gijsberts, Michael A. Echteld, Jenny T. van der Steen, Martien T. Muller, René H.J. Otten, Miel W. Ribbe, Luc Deliens. 2011. Spirituality at the End of Life: Conceptualization of Measurable Aspects-a Systematic Review. Journal of Palliative Medicine 14:7, 852-863. [Abstract] [Full Text HTML] [Full Text PDF] [Full Text PDF with Links]

77. Kimberly S. Johnson, James A. Tulsky, Judith C. Hays, Robert M. Arnold, Maren K. Olsen, Jennifer H. Lindquist, Karen E. Steinhauser. 2011. Which Domains of Spirituality are Associated with Anxiety and Depression in Patients with Advanced Illness?. Journal of General Internal Medicine 26:7, 751-758. [CrossRef]

78. Chaplain Bruce D. Feldstein. 2011. Bridging with the Sacred: Reflections of an MD Chaplain. Journal of Pain and Symptom Management 42:1, 155-161. [CrossRef]

79. Katherine R. B. Jankowski, George F. Handzo, Kevin J. Flannelly. 2011. Testing the Efficacy of Chaplaincy Care. Journal of Health Care Chaplaincy 17:3-4, 100-125. [CrossRef]

80. William Breitbart, Allison ApplebaumMeaning-Centered Group Psychotherapy 137-148. [CrossRef]

81. George Fitchett, Kathryn A. Lyndes, Wendy Cadge, Nancy Berlinger, Erin Flanagan, Jennifer Misasi. 2011. The Role of Professional Chaplains on Pediatric Palliative Care Teams: Perspectives from Physicians and Chaplains. Journal of Palliative Medicine 14:6, 704-707. [Abstract] [Full Text HTML] [Full Text PDF] [Full Text PDF with Links]

82. John H Kearsley. 2011. In the nighttime of your fear: The anatomy of compassion in the healing of the sick. Palliative and Supportive Care 9:02, 215-221. [CrossRef]

83. Lucy Selman, Richard Siegert, Richard Harding, Marjolein Gysels, Peter Speck, Irene J. Higginson. 2011. A Psychometric Evaluation of Measures of Spirituality Validated in Culturally Diverse Palliative Care Populations. Journal of Pain and Symptom Management . [CrossRef]

84. Jinsun Yong, Juhu Kim, Junyang Park, Imsun Seo, John Swinton. 2011. Effects of a Spirituality Training Program on the Spiritual and Psychosocial Well-Being of Hospital Middle Manager Nurses in Korea. The Journal of Continuing Education in Nursing 42:6, 280-288. [CrossRef]

85. Marvin O. Delgado-Guay, David Hui, Henrique A. Parsons, Kathy Govan, Maxine De la Cruz, Steven Thorney, Eduardo Bruera. 2011. Spirituality, Religiosity, and Spiritual Pain in Advanced Cancer Patients. Journal of Pain and Symptom Management 41:6, 986-994. [CrossRef]

86. Ronald L. Ettinger. 2011. EDITORIAL. Special Care in Dentistry 31:3, 75-76. [CrossRef]

87. Judith A. Paice, Betty Ferrell. 2011. The management of cancer pain. CA: A Cancer Journal for Clinicians 61:3, 157-182. [CrossRef]

88. Michael J. Balboni, Amenah Babar, Jennifer Dillinger, Andrea C. Phelps, Emily George, Susan D. Block, Lisa Kachnic, Jessica Hunt, John Peteet, Holly G. Prigerson, Tyler J. VanderWeele, Tracy A. Balboni. 2011. "It Depends": Viewpoints of Patients, Physicians, and Nurses on Patient-Practitioner Prayer in the Setting of Advanced Cancer. Journal of Pain and Symptom Management 41:5, 836-847. [CrossRef]

89. Caprice Knapp, Vanessa Madden, Hua Wang, Charlotte Curtis, Phyllis Sloyer, Elizabeth Shenkman. 2011. Spirituality of Parents of Children in Palliative Care. Journal of Palliative Medicine 14:4, 437-443. [Abstract] [Full Text HTML] [Full Text PDF] [Full Text PDF with Links]

90. C. Joly, A. Lainé, A. Catan, F. Pochard. 2011. L’interdisciplinarité : une visée, une nécessité et une exigence au service du malade. Éthique \& Santé. [CrossRef]

91. Lois Ramondetta, Alaina Brown, Gwyn Richardson, Diana Urbauer, Premal H. Thaker, Harold G. Koenig, Jacalyn B. Gano, Charlotte Sun. 2011. Religious and Spiritual Beliefs of Gynecologic Oncologists May Influence Medical Decision Making. International Journal of Gynecological Cancer 21:3, 573-581. [CrossRef] 
92. Lucy Selman, Richard Harding, Marjolein Gysels, Peter Speck, Irene J. Higginson. 2011. The Measurement of Spirituality in Palliative Care and the Content of Tools Validated Cross-Culturally: A Systematic Review. Journal of Pain and Symptom Management 41:4, 728-753. [CrossRef]

93. Patricia Boston, Anne Bruce, Rita Schreiber. 2011. Existential Suffering in the Palliative Care Setting: An Integrated Literature Review. Journal of Pain and Symptom Management 41:3, 604-618. [CrossRef]

94. Arjan W. Braam, Marianne Klinkenberg, Dorly J.H. Deeg. 2011. Religiousness and Mood in the Last Week of Life: An Explorative Approach Based on After-Death Proxy Interviews. Journal of Palliative Medicine 14:1, 31-37. [Abstract] [Full Text HTML] [Full Text PDF] [Full Text PDF with Links]

95. Janie Brooks, Reverend Kathleen Ennis-DurstineFaith, Hope, and Love 111-118. [CrossRef]

96. Caitlin W. Brennan, Maryjo Prince-Paul, Clareen A. Wiencek. 2011. Providing a "Good Death” for Oncology Patients During the Final Hours of Life in the Intensive Care Unit. AACN Advanced Critical Care 22:4, 379-396. [CrossRef]

97. E. Benito. 2011. Los cuidados espirituales, entraña de los cuidados paliativos. Medicina Paliativa 18:1, 1-3. [CrossRef]

98. Katie A. Stewart. 2011. The Spiritual Framework of Coping Through the Voices of Cancer Survivor Narratives. OMEGA--Journal of Death and Dying 63:1, 45-77. [CrossRef]

99. Joan Halifax. 2011. The Precious Necessity of Compassion. Journal of Pain and Symptom Management 41:1, 146-153. [CrossRef]

100. Tracy Balboni, Michael Balboni, M. Elizabeth Paulk, Andrea Phelps, Alexi Wright, John Peteet, Susan Block, Chris Lathan, Tyler VanderWeele, Holly Prigerson. 2011. Support of cancer patients' spiritual needs and associations with medical care costs at the end of life. Cancer n/a-n/a. [CrossRef]

101. Jeffrey Burns, Cynda H. RushtonPalliative Care 115-121. [CrossRef]

102. Brenda M. Sabo, Mary L.S. VachonCare of professional caregivers 575-589. [CrossRef]

103. Susan E. McClement, Harvey M. ChochinovSpirituality in supportive oncology 521-525. [CrossRef]

104. Joan L. Rosenbaum, Joan Renaud Smith, Reverend Zollfrank. 2011. Neonatal End-of-Life Spiritual Support Care. The Journal of Perinatal \& Neonatal Nursing 25:1, 61-69. [CrossRef]

105. J. Mark Lazenby. 2010. On "spirituality," “religion," and "religions": A concept analysis. Palliative and Supportive Care 8:04, 469-476. [CrossRef]

106. Helen Lavretsky. 2010. Spirituality and aging. Aging Health 6:6, 749-769. [CrossRef]

107. Sara N. Davison, Gian S. Jhangri. 2010. Existential and Supportive Care Needs Among Patients with Chronic Kidney Disease. Journal of Pain and Symptom Management 40:6, 838-843. [CrossRef]

108. Adrienne Penderell, Kevin Brazil. 2010. The spirit of palliative practice: A qualitative inquiry into the spiritual journey of palliative care physicians. Palliative and Supportive Care 8:04, 415-420. [CrossRef]

109. M. Bregni. 2010. Quality of life and meaning of life: measuring the unmeasurable. Journal of Medicine and the Person 8:2, 60-64. [CrossRef]

110. Rebecca L. Sudore, Patrice Villars, Elise C. Carey. 2010. Sitting with You in Your Suffering: Lessons about Intractable Pain at the End of Life. Journal of Palliative Medicine 13:6, 779-782. [Abstract] [Full Text HTML] [Full Text PDF] [Full Text PDF with Links]

111. Sheila LoboPrabhu, James Lomax. 2010. The role of spirituality in medical school and psychiatry residency education. International Journal of Applied Psychoanalytic Studies 7:2, 180-192. [CrossRef]

112. Sara R. Alcorn, Michael J. Balboni, Holly G. Prigerson, Amy Reynolds, Andrea C. Phelps, Alexi A. Wright, Susan D. Block, John R. Peteet, Lisa A. Kachnic, Tracy A. Balboni. 2010. "If God Wanted Me Yesterday, I Wouldn't Be Here Today": Religious and Spiritual Themes in Patients' Experiences of Advanced Cancer. Journal of Palliative Medicine 13:5, 581-588. [Abstract] [Full Text HTML] [Full Text PDF] [Full Text PDF with Links]

113. Susan R. Mazanec, Barbara J. Daly, Sara L. Douglas, Amy R. Lipson. 2010. The Relationship Between Optimism and Quality of Life in Newly Diagnosed Cancer Patients. Cancer Nursing 33:3, 235-243. [CrossRef] 